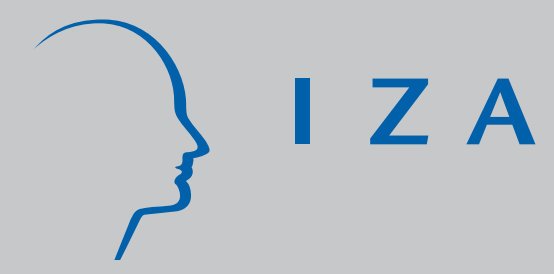

IZA DP No. 1586

Wage Growth and J ob Mobility in the U.K. and Germany

Christian Dustmann

Sonia C. Pereira

May 2005 


\title{
Wage Growth and Job Mobility in the U.K. and Germany
}

\author{
Christian Dustmann \\ University College London \\ and IZA Bonn \\ Sonia C. Pereira \\ University College London \\ and Yale University
}
Discussion Paper No. 1586
May 2005

\author{
IZA \\ P.O. Box 7240 \\ 53072 Bonn \\ Germany \\ Phone: +49-228-3894-0 \\ Fax: +49-228-3894-180 \\ Email: iza@iza.org
}

\begin{abstract}
Any opinions expressed here are those of the author(s) and not those of the institute. Research disseminated by IZA may include views on policy, but the institute itself takes no institutional policy positions.

The Institute for the Study of Labor (IZA) in Bonn is a local and virtual international research center and a place of communication between science, politics and business. IZA is an independent nonprofit company supported by Deutsche Post World Net. The center is associated with the University of Bonn and offers a stimulating research environment through its research networks, research support, and visitors and doctoral programs. IZA engages in (i) original and internationally competitive research in all fields of labor economics, (ii) development of policy concepts, and (iii) dissemination of research results and concepts to the interested public.
\end{abstract}

IZA Discussion Papers often represent preliminary work and are circulated to encourage discussion. Citation of such a paper should account for its provisional character. A revised version may be available directly from the author. 


\section{ABSTRACT}

\section{Wage Growth and Job Mobility in the U.K. and Germany*}

This paper investigates job mobility and estimates the returns to tenure and experience in the United Kingdom and Germany. We show evidence that job mobility is higher in the UK than in Germany, and that job movers may be negatively selected in Germany, but not in the UK. Our findings suggest that returns to experience are substantially higher in the UK. According to our estimates, ten years of labour market experience are associated with average wage returns of around 70 percent in the UK and 30 percent in Germany. Separate estimates for different qualification groups show that in Germany, it is the group of workers with apprenticeship training that is driving the low returns to labour market experience, while wages growth due to labour market experience is similar between the two countries for the other skill groups. Furthermore, returns to tenure are close to zero in both countries, while wage growth due to the macro trend is markedly higher in Germany.

JEL Classification: J24, J31

Keywords: returns to seniority, job mobility, asymmetric information

Corresponding author:

Christian Dustmann

Department of Economics

University College London

Gower Street

London WC1E 6BT

United Kingdom

Email: c.dustmann@ucl.ac.uk

\footnotetext{
*We are grateful to Joe Altonji, Margherita Borella and Rob Euwals for comments and suggestions. Sonia Pereira thanks the PRAXIS XXI Program, the British Chevening Scholarship and the Economic and Social Research Council for financial support and the Economic Growth Center at Yale University for its hospitality. Parts of this paper have been written while Christian Dustmann visited the Research School of Social Sciences (RSSS) at the Australian National University. He would like to thank the RSSS for its hospitality.
} 


\section{Introduction}

In this paper we analyse job mobility and wage growth for two large European economies that are possibly polar in terms of their labour market institutions and regulations: The United Kingdom and Germany. We focus our analysis on the relative magnitude of the effects of tenure in the firm and experience in the labour market for wage growth of workers in the two countries. Other than most previous work, our analysis allows for different tenureand experience profiles for different education groups. For our empirical analysis, we use two panel data sets, the British Household Panel Survey and the German Socio-Economic Panel.

There has been an extensive debate on the measurement of the impact of job seniority on wages, while the effect of general labour market experience on wages has attracted much less interest. Job tenure and general experience are understood as measures of job-specific and general human capital, and their association with wages is often interpreted as effects of specific and general human capital on individual wage profiles. Straightforward estimation confounds these effects with alternative mechanisms that induce correlation between labour market experience and tenure, and wages, as we will discuss below. Various estimators have therefore been suggested to address these problems (see Abraham and Farber 1987, Altonji and Shakotko 1987, Topel 1991, Altonji and Williams 1998 and Dustmann and Meghir 2005 among others).

While most of the papers in this literature have focused on particular countries, this paper investigates and compares job mobility and the determinants of wage growth for two countries with very different labour market institutions and patterns of job mobility: Germany and the U.K. According to the OECD Employment Outlook (1999) the UK is among the 
countries with least restrictive employment protection legislation, while Germany stands out for having relatively strict employment protection ${ }^{2}$, along with France and some Southern European countries. Moreover, unlike the UK, Germany has a tight corporatist labour market, with centralised wage negotiations. ${ }^{3}$ Although there are no legal minimum wages in Germany, and union membership is relatively low, union wage coverage affected about 76 percent of workers in the private sector in West Germany over the period between 1996-1999 (see Dustmann and Schoenberg 2004 for details). In the UK, and for the period under analysis (1991-1999) wages are less regulated ${ }^{4}$ and there is no minimum wage for most of the period ${ }^{5}$. Finally, Germany operates a vocational training system, combining state financed academic education with firm financed on the job training that trains about 65 percent of its workforce. These institutional disparities may play an important role in facilitating or hampering wage flexibility and job mobility, as well as affecting the way general and specific human capital relates to wage growth. Comparison of these two countries is also interesting in the light of the current debate about labour market de-regulation as well as vocational training programmes. The relatively flexible UK labour market is often seen as a model for labour market reforms that have yet to be implemented in Germany and other European economies.

\footnotetext{
${ }^{1}$ Our analysis focuses on former West Germany.

2 The indicators of strictness of employment protection used are based on the regulations concerning firing, e.g., redundancy procedures, mandated pre-notification periods and severance payments, special requirements for collective dismissals and short-time work schemes.

3 There are strong unions and employers' associations with autonomy to conclude collective agreements virtually on all matters of labour relations. The Federal Minister of Labor and Social Affairs estimates that, in 1990, the number of collective agreements in force was about 32000, encompassing almost all industries and services and about $90 \%$ of all employees (K.-L. Paque', 1993). Typically, these collective agreements fix contractual minima for wages and working conditions, and in practice virtually all organized employers offer the same wage and working conditions to union members and non-members alike.

${ }^{4}$ Union membership declined from 33.3 in 1991 to 26.9 in 1998. In 1998 union coverage was around 7 percentage points higher than union membership (Bland, 1999).

${ }^{5}$ Wage councils were abolished in 1993. They covered around 2.5 million employees in retailing, clothing and hairdressing. Their scope was reduced by the Wages Act 1986, which exempted workers under 21 and restricted the Councils to setting a unique minimum hourly rate for all covered workers. Minimum wages were reintroduced in the UK in April 1999, with a National Minimum Wage. (Metcalf, 1999; Emire database)
} 
We show evidence that job mobility is higher in the UK than in Germany and that job movers could be negatively selected in Germany, but not in the UK. Our analysis addresses possible bias in the returns to experience and tenure due to individual- and job match effects. Our findings suggest that the overall returns to tenure are small in both countries and that returns to experience are substantially higher in the UK than in Germany. According to our estimates, the first ten years of labour market experience are associated with average wage returns of 70 percent in the UK and 30 percent in Germany. Separate estimates for different qualification groups show that in Germany, it is the group of workers with apprenticeship training that drives down the returns to labour market experience. One interpretation is that apprenticeship training in Germany provides knowledge that is acquired during the first few years in the UK labour market. Both the unskilled and the university graduates' returns to experience do not differ much between the two countries. We also find that the macro trend is a more important contributor to wage growth in Germany than it is in the UK.

In our discussion of the results we suggest various possible explanations for the differences we observe in terms of selection and mobility. These are "stickier wages" in Germany (in models with employers' learning of workers' ability) and/or adverse selection of job movers in Germany due to low mobility in a context of asymmetric information between current and prospective employers about workers' ability.

This paper is organized as follows. Section 2 sets out the wage growth model and the estimation methods used. Section 3 describes the data. Section 4 provides descriptive statistics of job mobility, within and between jobs wage growth, and types of job separation. Section 5 presents the results, and section 6 discusses them in light of the institutional differences between the two countries and concludes. 


\section{Methods}

\subsection{The empirical model}

In our analysis, we wish to estimate the effects of general and firm specific human capital on wages. We assume that workers obtain the full return to the first. It is not clear how much of the return to specific human capital is captured by the worker, and we assume that the worker shares the returns to the latter with the employee. ${ }^{6}$ Let

$$
\ln H_{i j t}=g\left(T_{i j t}\right)+f\left(X_{i j t}\right)+m_{i j t}
$$

be the part of human capital the worker gets paid for, with $g\left(T_{i j t}\right)$ and $f\left(X_{i j t}\right)$ being functions in tenure and labour market experience, and $m_{i j t}$ a composite of individual and job match specific effect. Further, define the wage as $w_{i j t}=H_{i j t} e^{\gamma_{t}+v_{i j t}}$, where $\gamma_{t}$ are economy wide macro shocks and $v_{i j t}$ are transitory shocks and measurement error. ${ }^{7}$

Assuming for expositional purposes that $\mathrm{g}$ and $\mathrm{f}$ are linear functions in experience and tenure (we will estimate higher order polynomials below) and taking logs, we obtain the following wage equation:

\footnotetext{
${ }^{6}$ See Becker (1993) for an illuminating discussion of an equilibrium where employers share the return on specific human capital with employees. See Hashimoto (1981), Harris and Felli (1996) and Scoones and Bernhard (1996) for equilibrium models on how returns are shared between employer and employee. Parent (2002) points out that finding no returns to firm tenure does not imply that firm-specific human capital is not important, and offers an approach of assessing the importance of firm specific human capital based on second moments.

${ }^{7}$ A more flexible model has been proposed by Dustmann and Meghir (2004). They allow for differences in career paths between individuals. The quality of a match is reflected not only by the match specific productivity, but also by the steepness of the career profile within a given firm. They also allow for individual specific experience profiles. Their more general model requires additional identifying information which is not available in the surveys we are using.
} 


$$
W_{i j t}=\gamma_{t}+\beta_{1} X_{i j t}+\beta_{2} T_{i j t}+\varepsilon_{i j t}
$$

where $W_{i j t}$ is the $\log$ of the gross real hourly wage of individual $i$ on job $j$ at time $t, X_{i j t}$ is actual experience in the labour market, and $T_{i j t}$ is seniority with the current employer. The key parameters of interest, $\beta_{1}$ and $\beta_{2}$ give the partial effects of an additional year of experience or tenure on the wage, conditional on the components in the error term $\varepsilon_{i j t}$.

The error term $\varepsilon_{i j t}$ can be decomposed in three orthogonal components, $A_{i}, \theta_{i j}$ and $v_{i j t}$ :

$$
\varepsilon_{i j t}=\theta_{i j}+A_{i}+v_{i j t}
$$

where the individual fixed effect $A_{i}$ captures unmeasured differences in ability, the job-match effect $\theta_{i j}$ is fixed during the course of a job and allows for heterogeneity in the quality of the job matches, and the transitory component $v_{i j t}$ accounts for idiosyncratic shocks and measurement error.

If the unobserved individual and job match effects are correlated with tenure and/or experience, then least squares estimates of $\beta_{1}$ and $\beta_{2}$ are likely to be biased. To assess these biases, consider the following auxiliary regressions:

$$
\begin{aligned}
& A_{i}=b_{1} X_{i j t}+b_{2} T_{i j t}+\xi_{i j t} \\
& \theta_{i j}=c_{1} X_{i j t}+c_{2} T_{i j t}+\omega_{i j t}
\end{aligned}
$$

According to (4) and (5) in a cross-section of individuals, both the individual and the job match effects can be correlated with years of seniority and labour market experience. 
Least squares estimation of (2) is likely to produce biased estimates of returns to seniority and experience, with $\beta_{1}^{O L S}-\beta_{1}=b_{1}+c_{1}$ and $\beta_{2}^{O L S}-\beta_{2}=b_{2}+c_{2}$.

In order to assess the likely signs of these biases we use straightforward partitioned regression results applied to (4) and (5) to obtain explicit expressions for $b_{1}, b_{2}, c_{1}$ and $c_{2}$ in terms of the variances and covariances of the unobservable components and the variables of interest:

$$
\begin{aligned}
& b_{1}=\frac{\operatorname{Cov}\left(X_{i j t}, A_{i}\right)-\gamma_{T X} \operatorname{Cov}\left(T_{i j t}, A_{i}\right)}{\operatorname{Var}\left(X_{i j t}\right)\left[1-\rho_{X T}{ }^{2}\right]} ; b_{2}=\frac{\operatorname{Cov}\left(T_{i j t}, A_{i}\right)-\gamma_{X T} \operatorname{Cov}\left(X_{i j t}, A_{i}\right)}{\operatorname{Var}\left(T_{i j t}\right)\left[1-\rho_{X T}{ }^{2}\right]} \\
& c_{1}=\frac{\operatorname{Cov}\left(X_{i j t}, \theta_{i j}\right)-\gamma_{T X} \operatorname{Cov}\left(T_{i j t}, \theta_{i j}\right)}{\operatorname{Var}\left(X_{i j t}\right)\left[1-\rho_{X T}{ }^{2}\right]} ; c_{2}=\frac{\operatorname{Cov}\left(T_{i j t}, \theta_{i j}\right)-\gamma_{X T} \operatorname{Cov}\left(X_{i j t}, \theta_{i j}\right)}{\operatorname{Var}\left(T_{i j t}\right)\left[1-\rho_{X T}{ }^{2}\right]} .
\end{aligned}
$$

Here $\gamma_{T X}$ is the coefficient from a regression of experience on tenure, $\gamma_{X T}$ the coefficient from a regression of tenure on experience, and $\rho_{X T}$ the correlation coefficient between $X$ and $T$. It is clear from these expressions that a bias in estimating the returns to labour market experience may affect the estimate of the return to tenure and vice versa, as tenure and experience are correlated with each other.

Consider first the covariance between job tenure and unobserved ability, $\operatorname{cov}\left(T_{i j t}, A_{i}\right)$. If individuals with high unobserved ability (comprising characteristics such as perseverance, motivation, or health status) have more stable work relationships and avoid job turnover, then this expression should be positive. ${ }^{8}$ In addition, asymmetric employer learning about workers' ability may contribute to more able individuals having longer job spells (see Schönberg 2004), as high ability individuals face a disincentive to move jobs due to adverse selection 
(see Gibbons and Katz, 1991, Acemoglu and Pischke, 1998). Both reasons lead to $\operatorname{cov}\left(T_{i j t}, A_{i}\right)>0$

The covariance between labour market experience and ability, $\operatorname{cov}\left(X_{i j t}, A_{i}\right)$, is positive if high ability workers have a higher labour market attachment. This would mean that experience in the labour market $X_{i j t}$ is likely to be positively correlated with the individual fixed effect $A_{i}{ }^{9}: \operatorname{cov}\left(X_{i j t}, A_{i}\right)>0$. Topel (1991), Altonji and Shakotko (1987) and Altonji and Williams (2005) all exclude such a correlation. As Altonji and Williams (2005) point out, this assumption implies that worker quality is independent of birth cohort, and that high and low wage workers have similar labour force attachment. Altonji and Shakotko (1987) conclude that the latter is likely to hold in their data. ${ }^{10}$

Job search theory of job mobility suggests that on average match quality improves with experience, as the expected maximum of a wage offer received from a fixed wage distribution increases with time in the labour market (Burdett, 1978 and Jovanovic, 1979). This leads to a positive correlation between labour market experience and the job match effect, so that $\operatorname{cov}\left(X_{i j t}, \theta_{i j}\right)>0$.

Similarly, if good matches are more likely to survive, the job-match effect and tenure are positively correlated. As pointed out by Altonji and Williams (2005), this positive correlation will be reinforced if firms share the returns to a good match. However, Topel

\footnotetext{
${ }^{8}$ Blumen et al. (1955) develop a model where mobility is negatively related to wages because high turnover workers are of low permanent productivity. See Light and McGarry (1998) for a discussion and a test of this model.

${ }^{9}$ Experience may also be positively correlated with the individual fixed effect if average workers' ability differs across cohorts. We assume that average workers' ability is similar across different cohorts, conditional on experience, tenure and the other controls included in the empirical regression.

${ }^{10}$ For European countries, this may be different. To test this assumption, we have computed permanent wages for individuals as fixed effects of a regression of log wages on an age polynomial and year dummies. We have then regressed labour market experience on potential experience and dummies for the individual's quartile location in the permanent wage distribution. For both Germany and the UK, individuals in the lower quartile(s)
} 
(1991) argues that selection may lead to a negative correlation. Suppose good matches are not more likely to survive and there are no returns to tenure $\left(\beta_{2}=0\right)$. In this case, the distribution of maximum offers depends only on the number of offers received (which is proportional to experience), but not on their order (which is proportional to tenure), so that $\operatorname{cov}\left(T_{i j t}, \theta_{i j}\right)=0$. If however returns to tenure are positive, individuals will turn down job offers that would otherwise be acceptable, and move only if offers are sufficiently high to compensate for forgone returns in tenure. This lowers the job match for individuals who stay with a firm, and increases the job match for individuals who move (and are observed with low tenure), leading to a negative correlation between the job match effect and tenure. Overall, the sign of $\operatorname{cov}\left(T_{i j t}, \theta_{i j}\right)$ is ambiguous.

Now reconsider the expressions in (6) and (7), and consider $b_{1}$ and $b_{2}$ first. In case that $\operatorname{cov}\left(X_{i j t}, A_{i}\right)=0, b_{1}$ will be negative and $b_{2}$ positive for $\gamma_{T X}>0$. The correlation between tenure and experience induces a downward bias in experience, even if experience and unobserved productivity are not correlated: an overestimate of tenure must lead to an underestimate of experience. The intuition is the following. Returns to experience are identified from returns to tenure when workers change jobs, since during the course of a job, changes in tenure and experience are perfectly co-linear. If in a cross-section of workers, job duration and the individual fixed effects are positively correlated, low ability workers are over-represented among job movers. This could both overstate the estimated effect of job tenure on wages and understate the estimated effect of labour market experience on wages. If $\operatorname{cov}\left(X_{i j t}, A_{i}\right)>0$, none of the two terms can be signed.

of the distribution have a significantly lower level of experience, controlling for potential experience; however, the size of these differences is small. 
The biases in experience and tenure due to job match effects can likewise not be signed. They depend on the relative magnitudes of the covariance of tenure and experience with the job quality, as well as on the sign of the correlation between the job quality and tenure.

\subsection{Estimation}

The estimators we use are the instrumental variable estimator suggested by Altonji and Shakotko (1987), and Finnie's (1993) modification of the Altonji and Shakotko estimator. A clear attraction of these methods is their simplicity and low data requirements, which allows us to apply them to both data sets. For this reason the Altonji and Shakotko (1987) instrumental variable estimator has also been used to study extensions of the standard wage model such as the returns to industry specific capital (Parent, 1999) and the impact of employer-provided training on wages (Parent, 2000), as well as to investigate the evolution of the wage premium for job seniority in the US (Marcotte, 1998).

In Altonji and Shakotko's (1987) approach, each of the tenure variables is instrumented with its deviations from job means $D T_{i j t}$. Let $\bar{T}_{i j}$ be the job mean of the tenure variable, then $D T_{i j t}=T_{i j t}-\bar{T}_{i j}$. As this variable has zero mean within each job, it is by construction orthogonal to the fixed individual and job match components. ${ }^{11}$ Hereafter we will call the estimation method of instrumenting tenure with its deviations from job means IVten $1 .{ }^{12}$

\footnotetext{
${ }^{11}$ In our empirical analysis we also include higher order terms in tenure that are instrumented in the same way.

12 Topel (1991) shows that this estimator is equivalent (at least for the linear case) to his two step estimator, where macro effects are pre-estimated, and where in his second step, experience is used as an instrument for experience at the start of a job.
} 
Applying IVten I to (1) may still produce biased estimates of returns to seniority and experience. Consider a variable $\hat{T}_{i j t}$ containing the predicted values of a regression of tenure on its deviations from job means. The resulting expressions can be easily derived as

$$
\begin{aligned}
b_{1}^{\text {IVten } 1}=\frac{\operatorname{Cov}\left(X_{i j t}, A_{i}\right)}{\operatorname{Var}\left(X_{i j t}\right)\left[1-\rho_{X \hat{T}}^{2}\right]} ; & b_{2}^{I V t e n 1}=\frac{-\gamma_{X \hat{T}} \operatorname{Cov}\left(X_{i j t}, A_{i}\right)}{\operatorname{Var}\left(\hat{T}_{i j t}\right)\left[1-\rho_{X \hat{T}}^{2}\right]} \\
c_{1}^{\text {IVten } 1}=\frac{\operatorname{Cov}\left(X_{i j t}, \theta_{i j}\right)}{\operatorname{Var}\left(X_{i j t}\right)\left[1-\rho_{X \hat{T}}{ }^{2}\right]} ; & c_{2}^{\text {IVten } 1}=\frac{-\gamma_{X \hat{T}} \operatorname{Cov}\left(X_{i j t}, \theta_{i j}\right)}{\operatorname{Var}\left(\hat{T}_{i j t}\right)\left[1-\rho_{X \hat{T}}{ }^{2}\right]} .
\end{aligned}
$$

A positive correlation between experience and the job match effect may lead to an upward bias of the experience effect and a downward bias of the tenure effect. Both effects are reinforced by any remaining ability bias in the experience variable.

As an attempt to compare the relative importance of the individual and job heterogeneity bias in the two countries, in our empirical section we also use as an alternative instrumental variable for tenure its deviations from individual means. We call this instrumental variable estimator IVten2. Intuitively, while IVten2 would represent an improvement over least squares since it produces an estimate of returns to tenure free from the bias due to the correlation between tenure and the individual fixed effect, IVten I produces an estimate of returns to tenure free from the bias due to the correlation between tenure and both the individual and job match effects. A comparison of least squares, IVtenI and IVten2, could give an indication of the relative importance of individual and job match heterogeneity in the returns to tenure. Indirectly, this could give evidence of the relative importance of the correlation between ability and job duration, and job match quality and job duration in the two countries. Such evidence would not however be conclusive, as can be seen by comparing the 
expressions of the remaining biases in the returns to tenure and experience for IVten 2 with the ones for IVtenI above (shown in appendix 3).

To take account of the correlation between labour market experience and the individual effect, this estimator can be extended by using as an instrument for experience its deviations from individual means, ${ }^{13} \operatorname{DExp}_{i j t}=\operatorname{Exp}_{i j t}-\overline{\operatorname{Exp}}_{i}$, where $\overline{\operatorname{Exp}}_{i j t}$ is the individual mean of the experience variables. Extension to higher order polynomials is straightforward. As this variable has zero average over each individual, it is by construction orthogonal to the individual fixed effect: $b_{1}^{\text {IVtenexp }}=0$ and $b_{2}^{\text {IVten exp }}=0$. Experience instruments can still nevertheless be correlated with the job match component, leading to a positive bias in experience and a negative bias in returns to tenure:

$$
c_{1}^{I V t e n \exp }=\frac{\operatorname{Cov}\left(\hat{X}_{i j t}, \theta_{i j}\right)}{\operatorname{Var}\left(\hat{X}_{i j t}\right)\left[1-\rho_{\hat{X} \hat{T}}{ }^{2}\right]} ; \quad c_{2}^{I V t e n e x p}=\frac{-\gamma_{\hat{X} \hat{T}} \operatorname{Cov}\left(\hat{X}_{i j t}, \theta_{i j}\right)}{\operatorname{Var}\left(\hat{T}_{i j t}\right)\left[1-\rho_{\hat{X} \hat{T}}{ }^{2}\right]} .
$$

We refer to the instrumental variables estimator that uses $D \operatorname{Exp}_{i j t}$ as an additional instrument for experience as IVtenexp. Both IVtenI and IVtenexp give upward bounds to returns to experience and lower bounds to returns to tenure.

A further problem in estimating equation (1) is the treatment of time effects, represented by $\gamma_{t}$. There are various reasons for why time may be correlated with job match effects or individual heterogeneity, as discussed by Altonji and Williams (2005). First, if average experience changes over the sample period, and is correlated with the job match component, then this induces a correlation between time and the job quality. Second, systematic panel attrition may lead to a correlation between time and unobserved productivity. Both problems can be addressed by using the deviation of time from its mean within

\footnotetext{
${ }^{13}$ This instrument has been used by Finnie (1993) and Parent (2000).
} 
individuals as an instrument for time in a regression conditional on experience and tenure. We have estimated models using these instruments, but estimates were practically identical to non-instrumented ones. We therefore use non-instrumented time dummies in our estimations below.

\section{The Data}

We briefly describe the two data sets used in this paper, with further details in Appendix 1.C. We use the first 9 waves of the British Household Panel Survey (1991-1999) and the first 14 waves of the German Socio-Economic Panel (1984-1997).

\subsection{The British Household Panel Survey}

The BHPS was designed as an annual survey of all adult (16+) members of a nationally representative sample of more than 5,000 households, making a total of approximately 10,000 individual interviews. The same individuals are followed in successive waves. In order to construct tenure and experience we use the retrospective data on past jobs collected in the second and third waves (1992 and 1993). For this reason, we may not be able to include adults of newly formed households with members that split off from the original households. We assume that this sample selection is random and does not affect the wage regressions as long as tenure and experience are included in the regressions.

At each wave the interviewees are asked to state the beginning date of the ongoing job spell, which is defined by a change of employer or a change of job within the same employer. We link this information collected at various waves to construct tenure with the employer. 
When linking the job spell information in the various yearly questionnaires and the retrospective data collected in waves 2 and 3 one is confronted with overlapping information for the same spell. Conflicting answers are resolved by giving priority to the information collected closest to the event occurrence. This is because recall error is likely to increase with the time elapsed between an event and the time of interview.

We restrict the sample to observations of non-self-employed white males aged between 16 and 60 with jobs in the private sector. The earnings variable used is real hourly wage. The real hourly wage is obtained by dividing the current job real gross monthly pay by 4.33 times weekly hours worked, where weekly hours is the sum of the number of normal hours worked per week and the number of overtime hours. Imputed wage values were discarded as well as 37 wage outliers ${ }^{14}$.

In our analysis we divide workers into three skill groups: unskilled, medium skilled and university graduates. For the UK data the unskilled include those who report the following qualifications: no qualifications, other qualifications, apprenticeship, CSE, commercial qualifications, no $\mathrm{O}$ levels. The medium skilled include those with $\mathrm{O}$ levels or equivalent, nursing qualifications, teaching qualifications and A- levels. Finally, the university graduates are those with a higher degree, a first degree, or other higher qualification.

\footnotetext{
${ }^{14}$ These include 17 observations with hourly wages less than 0.5 GBP, 6 observations with a within-job hourly wage decline of $85 \%$ between two consecutive years, and 14 observations with a within-job hourly wage growth larger than $500 \%$ between two consecutive years.
} 


\subsection{The German Socio-Economic Panel}

The GSOEP started in 1984 as a yearly longitudinal survey of 4298 private households ${ }^{15}$ and around 9000 individuals in West Germany. Although from 1990 data is also collected for former East Germany, we restrict our analysis to West Germany. Similar to the BHPS, in the GSOEP all household members are interviewed individually from the age of 16 . Our sample is also constructed in a similar way: only non-self-employed white males aged between 16 and 60 with jobs in the private sector are included.

The number of years of labour market experience is constructed in two stages. The first stage uses the yearly biographical scheme (included in the first wave, or the questionnaire to every new entrant) containing employment information from the age of 16 to construct total experience at the entry of the panel. Both part-time and full-time spells are considered. The second stage uses the calendar available for each wave listing all labour market activities for each month in the year preceding the interview. This information is added to the information computed in the first stage to construct experience at each wave. The tenure variable is constructed from the information about the exact year and month the individual has started the current job (i.e., the employment spell with the current employer), up to the time of interview. Wages are computed by dividing reported gross earnings in the month before the interview by the number of hours worked for pay.

The three skill groups considered are the following: workers with no post-secondary education (unskilled); workers with post-secondary apprenticeship training, but no university education (medium skilled); and workers with university degree - the university graduates (See appendix 1.C for more details).

\footnotetext{
${ }^{15}$ These numbers are for the GSOEP sub-sample A - "Residents in the FRG", 95\% scientific-use version.
} 
Finally, it we would like to stress that in both data sets we use, wage information refers unequivocally to the current main job, employer changes are identified, and tenure information is retrieved from monthly calendar information (GSOEP) or exact start date (BHPS). This avoids problem as noted in some of the work on tenure effects based on the PSID data (see Altonji and Shakatko 1987, Topel 1992, and Altonji and Williams 1998). While in the PSID, tenure and experience measures can be dated to the interview date, wage information is based on annual earnings, thus creating error in the exact allocation of tenure and experience to a particular wage spell (see Altonji and Williams 2005 for a discussion). This problem is aggravated by the fact that the PSID does not identify employers, so that employer changes are inferred from calendar time and tenure (see Brown and Light 1992 for a detailed discussion).

\section{Descriptive statistics}

\subsection{The Sample}

In Table 1 we show the mean sample characteristics for the two samples. There is a high degree of similarity between the two data sets. The average age is 37 in the UK and 39 in Germany and the mean experience is 20 years in the UK and 19 in Germany. When constructing labour market experience in Germany we did not include the apprenticeship training period, hence the larger age-experience gap in Germany than in the UK. Average tenure is on average two years longer in Germany than in the UK. 
Table 1: Summary Statistics - Mean sample characteristics for white males

U. K. - BHPS Germany - GSOEP

$\begin{array}{lcc}\text { Log real hourly wage } & 1.78 & 2.98 \\ & (0.43) & (0.38) \\ \text { Hours worked per week } & 39.8 & 40.8 \\ & (6.7) & (6.2) \\ \text { Tenure (years) } & 8.2 & 10.0 \\ & (7.9) & (9.5) \\ \text { Experience (years) } & 19.6 & 18.9 \\ & (11.6) & (12.0) \\ \text { Percent married } & 63.8 & 74.9 \\ & & \\ \text { Percent unskilled } & 26.09 & 13.70 \\ \text { Percent medium skilled/apprenticeship training } & 37.64 & 73.57 \\ \text { Percent university graduates } & 36.28 & 12.74 \\ & & \\ \text { Number of observations } & 7073 & 12302 \\ \text { Number of individuals } & 1502 & 2209 \\ \text { Number of jobs } & 2259 & 3053 \\ \text { Number of waves } & 9 & 14 \\ \text { Note: Standard deviations in parenthesis. UK wages are in British pounds and German wages are in Deutschmarks. }\end{array}$

\subsection{Wage growth: total, within jobs and between jobs}

Figure 1 illustrates the average yearly wage growth in both countries over the observation window ${ }^{16}$. Wage growth between two adjacent years is computed by averaging the difference in the log of the real hourly wage for all individuals observed in both periods. This does not necessarily coincide with total wage growth across all individuals, since it does not include those that enter and exit the panel ${ }^{17}$. In the years 1984-97, the real gross hourly wages in the German sample grew on average 3.23 per year and in the period 1991-99 the real gross hourly wages in the UK sample grew on average 2.87 per year. However, during the

\footnotetext{
${ }^{16}$ Nominal wages were deflated with the retail price index for each country. All figures and tables use real wages.

${ }^{17}$ Wage growth between 1984 and 1985 in Germany may be excessively low since unlike the other years where 80 to 95 percent of interviews take place between February and April, in 1984 by May only 50 percent of the interviews had taken place, and the remaining took place between May and September. Measurement error in yearly wage growth is therefore likely to be higher between 1984 and 1985. We expect the time dummies in our regression analysis to pick up the potential bias.
} 
years for which there is data for the two countries - 1991 to 1997 - the yearly wage growth was very similar in the two data sets (2.81 in Germany against 2.58 in the UK).

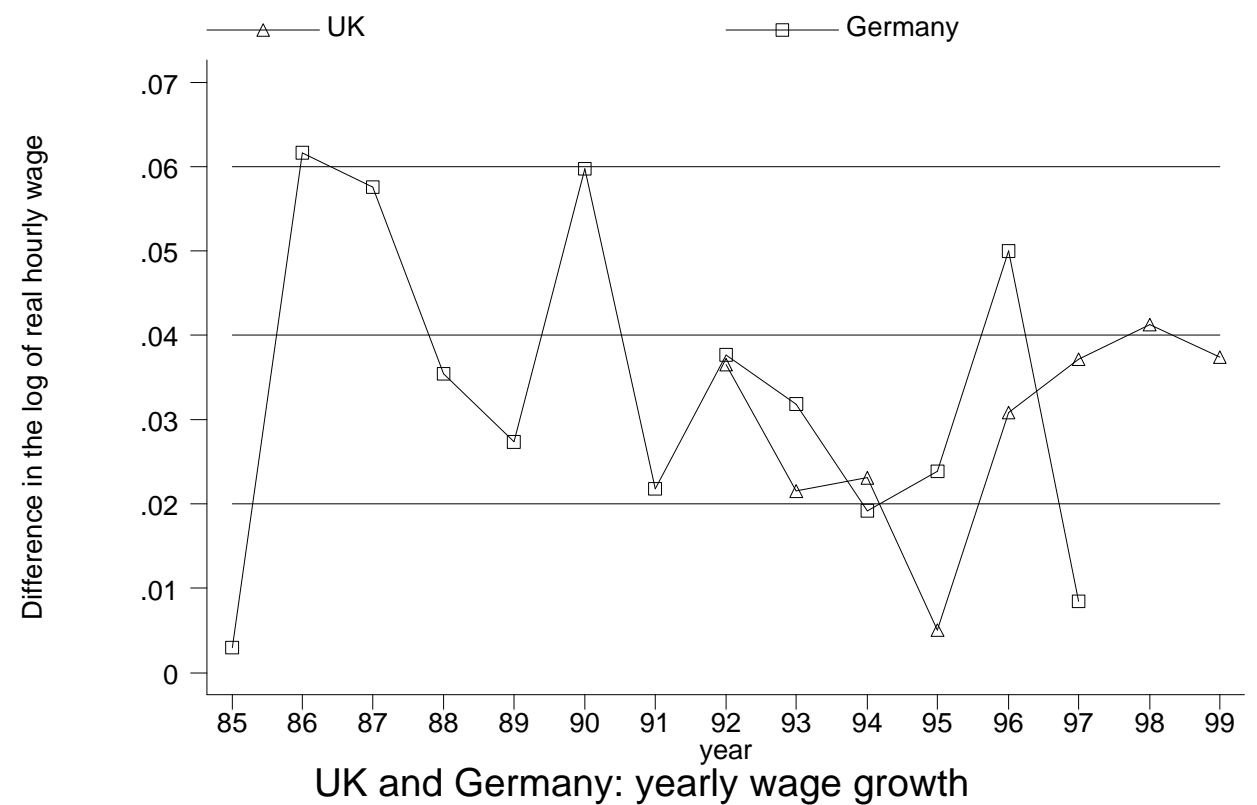

Figure 1: Yearly wage growth - UK and Germany
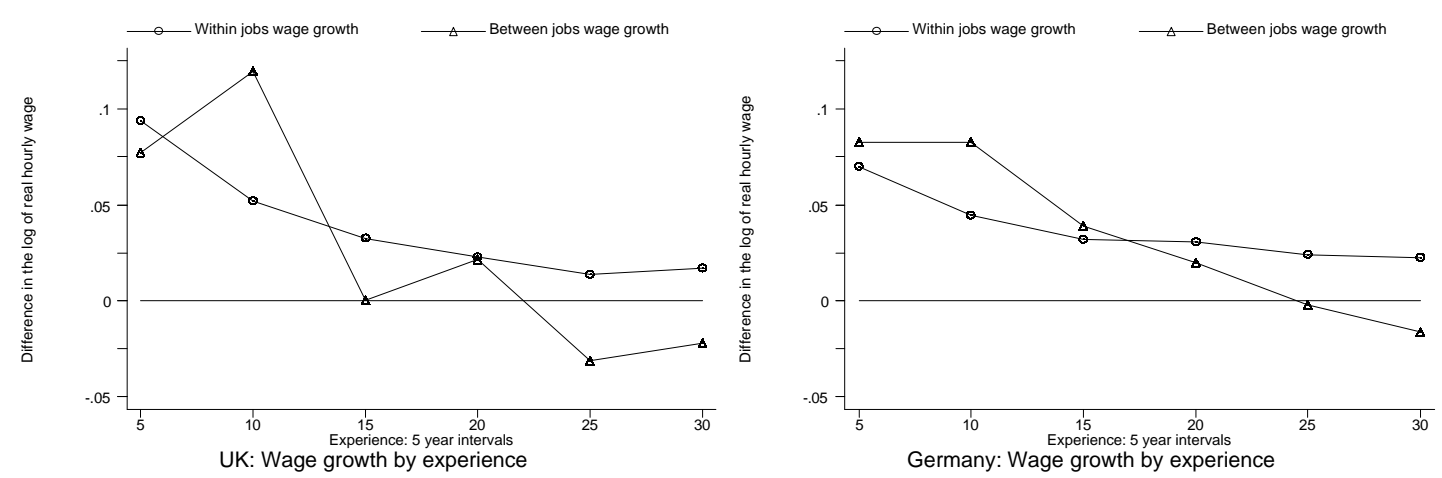

Figure 2: Wage growth by experience - UK and Germany

Figure 2 plots within and between jobs wage growth by 5 year experience intervals. For both countries between jobs wage growth is higher than within jobs wage growth in the first 10 to 15 years of workers' careers. After that, wage gains at job changes fall below 
within jobs wage growth, and become negative towards the end of individuals' careers. This is consistent with decreasing marginal returns to job search, and similar to what is reported for the US (see e.g. Topel and Ward 1992).

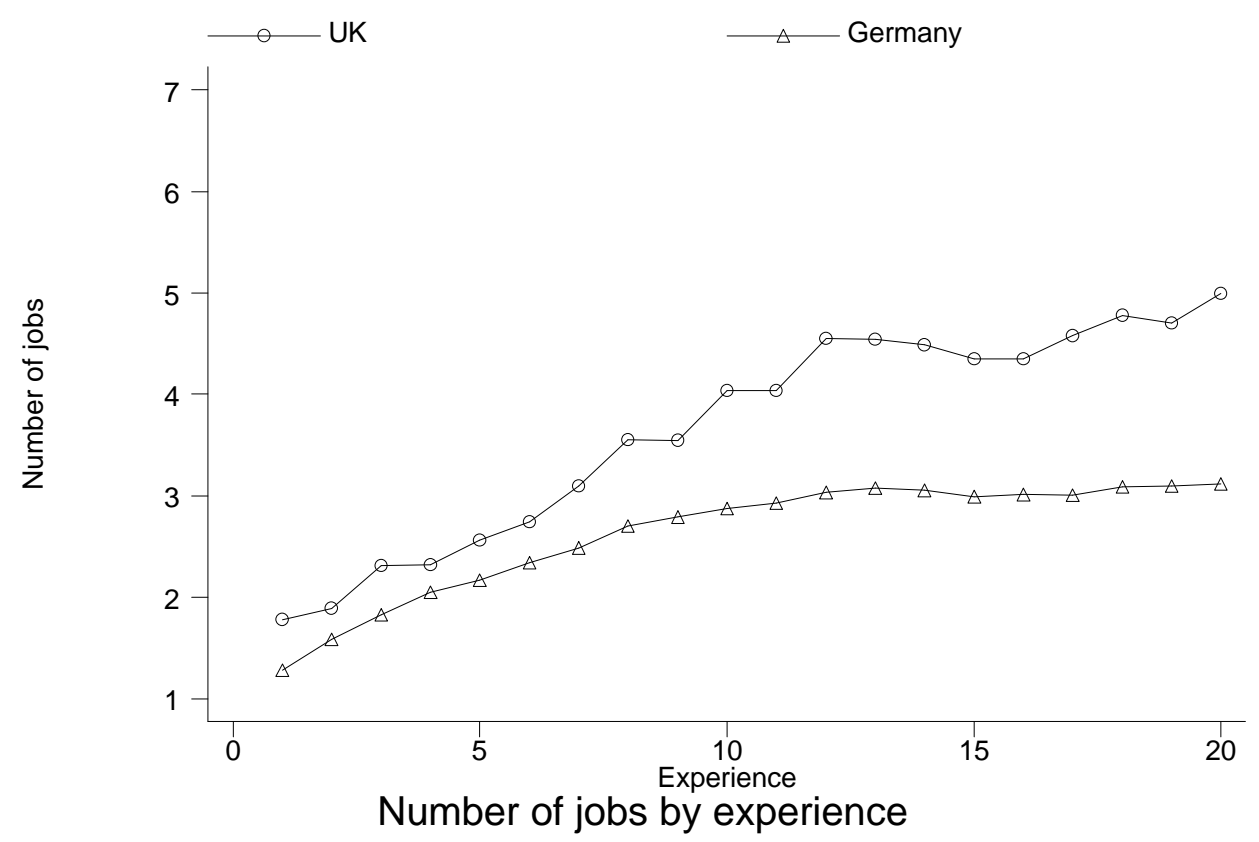

Figure 3: Number of jobs by experience - UK and Germany

In figure 3 , we display the number of jobs held by labour market experience ${ }^{18}$. British workers hold on average 4 jobs during the first ten years in the labour market, increasing to 5 jobs during the first 20 years, while German workers hold 2.9 jobs during the first 10 years, increasing only to 3.1 jobs during the first 20 years. Mobility is therefore clearly higher in the UK. However, in both countries the number of jobs held is small in comparison with the US,

\footnotetext{
${ }^{18}$ Due to the relative smaller number of observations in the UK, in figure 3 we apply a 3 year moving average to the variable "number of jobs".
} 
where workers hold on average 6.96 jobs during the first ten years of labour market experience $^{19}$ (p. 448, Topel and Ward 1992).
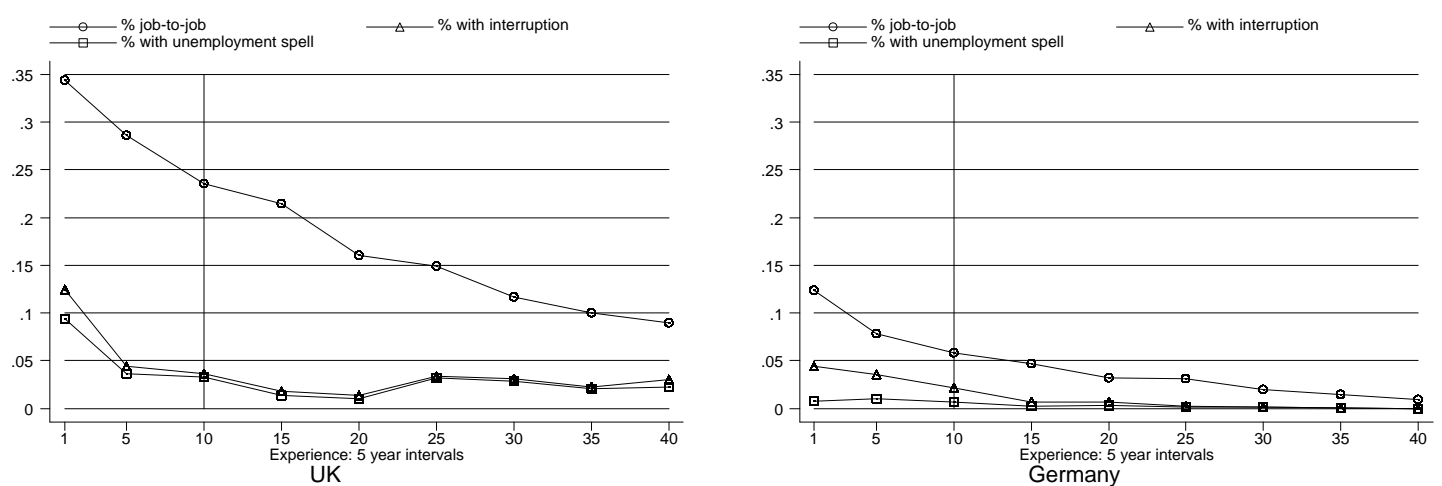

Figure 4: Types of transition between two waves in employment - UK and Germany

Figure 4 graphs the percentage of job-to-job transitions and job transitions with an unemployment spell between jobs on the total number of individuals observed in paid employment in two consecutive waves by 5-year experience interval. Unemployment is defined differently in the two data sets. While in the UK individuals report their own assessment of their labour market status, in Germany they are asked whether they are registered as unemployed. Because of this disparity, the figures also show the percentage of job-to-job transitions with an intermediate non-labour market spell. For Germany the gap between the share of transitions with unemployment and the share of transitions with a nonlabour market spell is larger than for the UK. This is consistent with a more stringent

\footnotetext{
${ }^{19}$ It is important to notice that Topel and Ward (1992) assume that a full-time work spell occurs when an individual earns at least 70 percent of the minimum quarterly wage during that quarter across all jobs. With the UK and German data work spells are defined by individuals classifying themselves as being employed as their main activity as opposed to full-time students. The difference between the average number of jobs during the first 10 years of labour market experience in the US and in the two European countries can therefore be slightly overstated if student Summer jobs are more likely to be excluded in the UK and German data.
} 
definition of unemployment status in the German data. In both countries both job-to-job transitions and transitions with interruptions decline with time in the labour market. This is consistent with decreasing marginal returns from search. These graphs are consistent with higher job mobility in the UK than in Germany since the occurrence of both types of transitions is higher in the former than in the latter for all experience categories. However, the difference between the occurrence of job-to-job transitions in the UK and Germany is much stronger than the difference in transitions with a non-employment spell. This is suggestive of a stronger role for voluntary job changes in the UK than in Germany.

\section{Estimating Returns to Experience and Tenure}

Table 2 shows the cumulative returns to tenure and experience in the two countries using the four estimation methods described: OLS, IVten1, IVten2 and IVtenexp. Table A1 in the appendix presents the coefficient estimates. All regressions use fourth degree polynomials in tenure and experience to allow for non-linear returns.

Columns 1 and 5 of table 2 show that according to OLS estimates ten years of tenure are associated with a 9.1 percent wage increase in the UK and an 8 percent wage increase in Germany. Interestingly, these values are considerably smaller than typical estimates based on US data, where ten years of tenure increase wages by 25 (Altonji and Shakatko 1987) and 30 percent (Topel 1991).

In columns 2 and 6 we present results where tenure is instrumented with its deviations from job means (IVten1). The returns to 10 years of tenure decline to 6.1 percent in the UK and to 2.2 percent in Germany, and loose statistical significance. This suggests that the correlation between tenure and the individual and job match effects generate a positive but small bias in the returns to tenure estimated by OLS. Taken at face value, the difference 
between the least squares and the IVtenl estimates of the tenure effect suggests that this bias is larger in Germany than in the UK. In columns 3 and 6 we present results where we instrument tenure with deviations from the individual means (IVten2). Recall that this estimator eliminates only the correlation between tenure and the effect of individual specific productivity, but not the correlation with the match specific effect. For the UK coefficient estimates for tenure are very similar to the ones using OLS (as are experience coefficients). Since IVten I produces an estimate of returns to tenure free from the bias due to the correlation between tenure and both the individual and job match effects this would be consistent with minor importance of individual heterogeneity bias in the UK; lower IVtenl estimates of the tenure effect compared to IVten2 suggests that least squares is positively biased mainly due to job match heterogeneity. However, as we discussed above (and illustrate in the appendix 3) the differences between these estimates are only suggestive of such interpretation, but offer no proof of that.

For Germany, the IVten2 and IVtenI estimates of the tenure effect are both lower than least squares estimates and very similar to each other. Returns to experience are higher than least squares and also very similar between IVten2 and IVten1. This is consistent with least squares having a positive bias mainly due to individual heterogeneity, but not due to job match heterogeneity. The evidence provided by the differences in the least squares, IVtenI and IVten2 estimates is consistent with more able workers having longer job durations in Germany, while in the UK the match quality is more important for the duration of an employment relationship. 
Table 2: Cumulative returns to tenure and experience - OLS and IV

\begin{tabular}{|c|c|c|c|c|c|c|c|c|}
\hline & \multicolumn{4}{|c|}{ UK } & \multicolumn{4}{|c|}{ Germany } \\
\hline & OLS & IVten1 & IVten2 & IVtenexp & OLS & IVten 1 & IVten 2 & IVtenexp \\
\hline & 1 & 2 & 3 & 4 & 5 & 6 & 7 & 8 \\
\hline \multirow[t]{2}{*}{1 year ten } & 0.0113 & 0.0131 & 0.0128 & 0.0135 & 0.0128 & 0.0035 & 0.0055 & -0.0015 \\
\hline & $(0.0047)^{*}$ & $(0.0093)$ & $(0.0073)$ & $(0.0091)$ & $(0.0031)^{* *}$ & $(0.0046)$ & $(0.0041)$ & $(0.0046)$ \\
\hline \multirow[t]{2}{*}{5 years ten } & 0.0508 & 0.0461 & 0.0525 & 0.0425 & 0.0506 & 0.0134 & 0.0179 & -0.0097 \\
\hline & $(0.0149)^{* *}$ & $(0.0290)$ & $(0.0217)^{*}$ & $(0.0269)$ & $(0.0098)^{* *}$ & $(0.0157)$ & $(0.0131)$ & (0.0149) \\
\hline \multirow[t]{2}{*}{10 years ten } & 0.0911 & 0.0611 & 0.0888 & 0.0442 & 0.0803 & 0.0224 & 0.0222 & -0.0211 \\
\hline & $(0.0168)^{* * *}$ & $(0.0371)$ & $(0.0252)^{* *}$ & $(0.0297)$ & $(0.0114)^{* *}$ & $(0.0228)$ & $(0.0172)$ & (0.0196) \\
\hline \multirow[t]{2}{*}{15 years ten } & 0.1253 & 0.0683 & 0.1244 & 0.0358 & 0.1067 & 0.0352 & 0.0268 & -0.0280 \\
\hline & $(0.0166)^{* *}$ & $(0.0485)$ & $(0.0301)^{* *}$ & $(0.0347)$ & $(0.0118)^{* *}$ & $(0.0311)$ & $(0.0214)$ & $(0.0239)$ \\
\hline \multirow[t]{2}{*}{1 year exp } & 0.0877 & 0.0898 & 0.0879 & 0.0854 & 0.0340 & 0.0366 & 0.0354 & 0.0467 \\
\hline & $(0.0063)^{* *}$ & $(0.0072)^{* *}$ & $(0.0067)^{* *}$ & $(0.0132)^{* *}$ & $(0.0038)^{* *}$ & $(0.0042)^{* *}$ & $(0.0041)^{* *}$ & $(0.0061)^{* *}$ \\
\hline \multirow[t]{2}{*}{5 years exp } & 0.4065 & 0.4192 & 0.4079 & 0.4101 & 0.1566 & 0.1721 & 0.1678 & 0.2196 \\
\hline & $(0.0296)^{* *}$ & $(0.0344)^{* *}$ & $(0.0314)^{* *}$ & $(0.0629)^{* *}$ & $(0.0152)^{* *}$ & $(0.0173)^{* *}$ & $(0.0167)^{* *}$ & $(0.0259)^{* *}$ \\
\hline \multirow[t]{2}{*}{10 years exp } & 0.6856 & 0.7141 & 0.6889 & 0.7353 & 0.2718 & 0.3067 & 0.3022 & 0.3932 \\
\hline & $(0.0473)^{* *}$ & $(0.0571)^{* *}$ & $(0.0505)^{* *}$ & $(0.1076)^{* *}$ & $(0.0221)^{* *}$ & $(0.0266)^{* *}$ & $(0.0249)^{* *}$ & $(0.0408)^{* *}$ \\
\hline \multirow[t]{2}{*}{15 years exp } & 0.8191 & 0.8623 & 0.8230 & 0.9449 & 0.3374 & 0.3913 & 0.3901 & 0.5107 \\
\hline & $(0.0519)^{* * *}$ & $(0.0664)^{* *}$ & $(0.0562)^{* *}$ & $(0.1348)^{* *}$ & $(0.0237)^{* *}$ & $(0.0317)^{* *}$ & $(0.0281)^{* *}$ & $(0.0484)^{* *}$ \\
\hline \multirow[t]{2}{*}{20 years exp } & 0.8472 & 0.9020 & 0.8496 & 1.0530 & 0.3553 & 0.4238 & 0.4279 & 0.5738 \\
\hline & $(0.0500)^{* *}$ & $(0.0697)^{* *}$ & $(0.0555)^{* *}$ & $(0.1541)^{* *}$ & $(0.0230)^{* *}$ & $(0.0364)^{* *}$ & $(0.0298)^{* *}$ & $(0.0527)^{* *}$ \\
\hline
\end{tabular}

Note: Log-wage returns to $k$ years of tenure (experience) with $k=1,5,10,15,20$ is the cross-product of the row vector of the tenure (experience) polynomial coefficients with a column vector of the form $\left(k, k^{2}, k^{3}, k^{4}\right)$. Values presented are the wage returns and are obtained by applying an exponential transformation to the log wage returns minus 1. Standard errors are the square root of a 1st order Taylor approximation of the corresponding variance.

As we pointed out above, because experience may be correlated with the individual and job error components, returns to experience are likely to be biased, which may in turn bias returns to tenure. Columns 4 and 8 show that when both tenure and experience are instrumented (IVtenexp), returns to tenure in both countries are lower than with any of the previous estimators. In addition returns to experience are somewhat higher than with the previous estimators both for the UK and Germany, and standard errors are also higher. Given 
that both IVtenI and IVtenexp give upward bounds to returns to experience and lower bounds to returns to tenure, we favour IVtenl.

In the lower panel of Table 2 we report the estimated returns to labour market experience. Overall, estimates point to higher returns to experience in the UK than in Germany according to the four estimation methods. Estimates using OLS, IVten1 and IVten2 are not very different. IVtenl estimates for the UK show that the first year in the labour market yields a return of about 9 percent, and by the 10th year in the labour market the resulting average cumulative return is roughly 70 percent. The marginal returns decrease with experience and the following 10 years generate another 20 percentage points wage gain. In Germany, IVtenl estimates a return to the first year in the labour market of only 3.6 percent, the first 10 years yield a cumulative wage gain of roughly 30 percent, and the first 20 years yield a 42 percent wage gain.

These differences in returns are quite dramatic. One reason may be that centralized wage negotiations in Germany allocate a larger part of wage growth to the economy wide time trend rather than to individual experience profiles. We investigate this below. Another reason may be that part of the general human capital that is acquired in the UK in the early years after labour market entry is acquired in Germany before entering the labour market, thus resulting in higher entry wages, but lower wage growth with respect to experience. The large initial wage growth in the UK is suggesting large increases in productivity at the start of a career. This explanation is quite plausible, as Germany operates a vocational training system (the apprenticeship system), which trains about 65 percent of its workforce. This system trains workers on the job (4 days a week) and in state run schools (1 day a week) for a period of between two and three years. To test this, we repeat our analysis, distinguishing between three different skill groups. 


\subsection{Cumulative returns to tenure and experience by skill group}

Table 3a: Cumulative returns to tenure and experience by qualification - UK

\begin{tabular}{|c|c|c|c|c|c|c|c|c|c|}
\hline & \multicolumn{3}{|c|}{ Unskilled } & \multicolumn{3}{|c|}{ Medium qualified } & \multicolumn{3}{|c|}{ University graduates } \\
\hline & OLS & IVtenI & IVtenexp & OLS & IVten1 & IVtenexp & OLS & IVten I & IVtenexp \\
\hline & 1 & 2 & 3 & 4 & 5 & 6 & 7 & 8 & 9 \\
\hline \multirow[t]{2}{*}{1 year ten } & 0.0135 & 0.0212 & 0.0190 & 0.0228 & 0.0076 & 0.0073 & -0.0054 & 0.0082 & 0.0107 \\
\hline & $(0.0090)$ & $(0.0205)$ & $(0.0186)$ & $(0.0083)^{* *}$ & $(0.0159)$ & $(0.0150)$ & $(0.0084)$ & $(0.0161)$ & $(0.0150)$ \\
\hline \multirow[t]{2}{*}{10 years ten } & 0.0870 & 0.0691 & 0.0398 & 0.0742 & 0.0042 & -0.0172 & 0.1055 & 0.0818 & 0.0885 \\
\hline & $(0.0341)^{*}$ & $(0.0936)$ & $(0.0621)$ & $(0.0268)^{* *}$ & $(0.0672)$ & $(0.0490)$ & $(0.0273)^{* *}$ & $(0.0655)$ & $(0.0471)$ \\
\hline \multirow[t]{2}{*}{15 years ten } & 0.1140 & 0.0438 & -0.0011 & 0.0728 & -0.0043 & -0.0480 & 0.1880 & 0.1114 & 0.1095 \\
\hline & $(0.0326)^{* *}$ & $(0.1181)$ & $(0.0724)$ & $(0.0260)^{* *}$ & $(0.0929)$ & $(0.0596)$ & $(0.0283)^{* *}$ & $(0.0826)$ & $(0.0535)$ \\
\hline \multirow[t]{2}{*}{1 year exp } & 0.0787 & 0.0791 & 0.0775 & 0.0809 & 0.0819 & 0.0679 & 0.1164 & 0.1150 & 0.1068 \\
\hline & $(0.0167)^{* *}$ & $(0.0193)^{* *}$ & $(0.0336)^{*}$ & $(0.0094)^{* *}$ & $(0.0117)^{* *}$ & $(0.0181)^{* *}$ & $(0.0120)^{* *}$ & $(0.0136)^{* *}$ & $(0.0268)^{* *}$ \\
\hline \multirow[t]{2}{*}{10 years exp } & 0.5794 & 0.6133 & 0.6712 & 0.7069 & 0.7419 & 0.6681 & 0.7808 & 0.7951 & 0.7195 \\
\hline & $(0.1176)^{* *}$ & $(0.1507)^{* *}$ & $(0.2593)^{*}$ & $(0.0701)^{* * *}$ & $(0.0948)^{* * *}$ & $(0.1381)^{* *}$ & $(0.0832)^{* *}$ & $(0.1000)^{* *}$ & $(0.2077)^{* *}$ \\
\hline \multirow[t]{2}{*}{20 years exp } & 0.6964 & 0.7834 & 1.0033 & 1.0283 & 1.1043 & 1.1154 & 0.7702 & 0.8234 & 0.7722 \\
\hline & $(0.1185)^{* *}$ & $(0.1873)^{* *}$ & $(0.3271)^{* *}$ & $(0.0772)^{* * *}$ & $(0.1375)^{* * *}$ & $(0.2004)^{* *}$ & $(0.0742)^{* *}$ & $(0.1031)^{* * *}$ & $(0.2507)^{* *}$ \\
\hline N. obsv. & 7073 & 7073 & 7073 & 7073 & 7073 & 7073 & 7073 & 7073 & 7073 \\
\hline $\mathrm{R} 2$ & 0.3136 & 0.2903 & 0.279 & 0.3136 & 0.2903 & 0.279 & 0.3136 & 0.2903 & 0.279 \\
\hline
\end{tabular}

Note: Log-wage returns to $k$ years of tenure (experience) with $k=1,5,10,15,20$ is the cross-product of the row vector of the tenure (experience) polynomial coefficients with a column vector of the form $\left(k, k^{2}, k^{3}, k^{4}\right)$. Values presented are the wage returns and are obtained by applying an exponential transformation to the log wage returns minus 1. Standard errors are the square root of a 1st order Taylor approximation of the corresponding variance.

Table $3 \mathrm{a}$ and $3 \mathrm{~b}$ displays the returns to tenure and experience by qualification group for the UK and Germany. Table A2 in the appendix reports coefficient estimates. Results in the table were obtained by interacting qualification dummies for the medium skilled and university graduates with the tenure and experience polynomials. Results are shown for OLS, IVten1 and IVtenexp. The various estimation methods differ in roughly the same way for each qualification group as for the whole sample of workers. For both countries and all skill groups IVtenl estimates show lower tenure effects than least squares, though IVtenl estimates are in most cases not significantly different from zero. In addition, with the exception of the 
university graduates in the UK, IVtenl offers a higher lower bound to the returns to tenure and a lower upper bound to the returns to experience than IVtenexp.

For the UK, IVtenl estimates of the returns to ten years of tenure are 7 percent for the unskilled, zero for the medium skilled and 8 percent for the university graduates. For Germany, IVtenl estimates of the returns to tenure are -4.4 percent for the unskilled, 3.5 for workers with apprenticeship training and zero for university graduates. However, none of these estimates are significantly different from zero.

Table 3b: Cumulative returns to tenure and experience by qualification - Germany

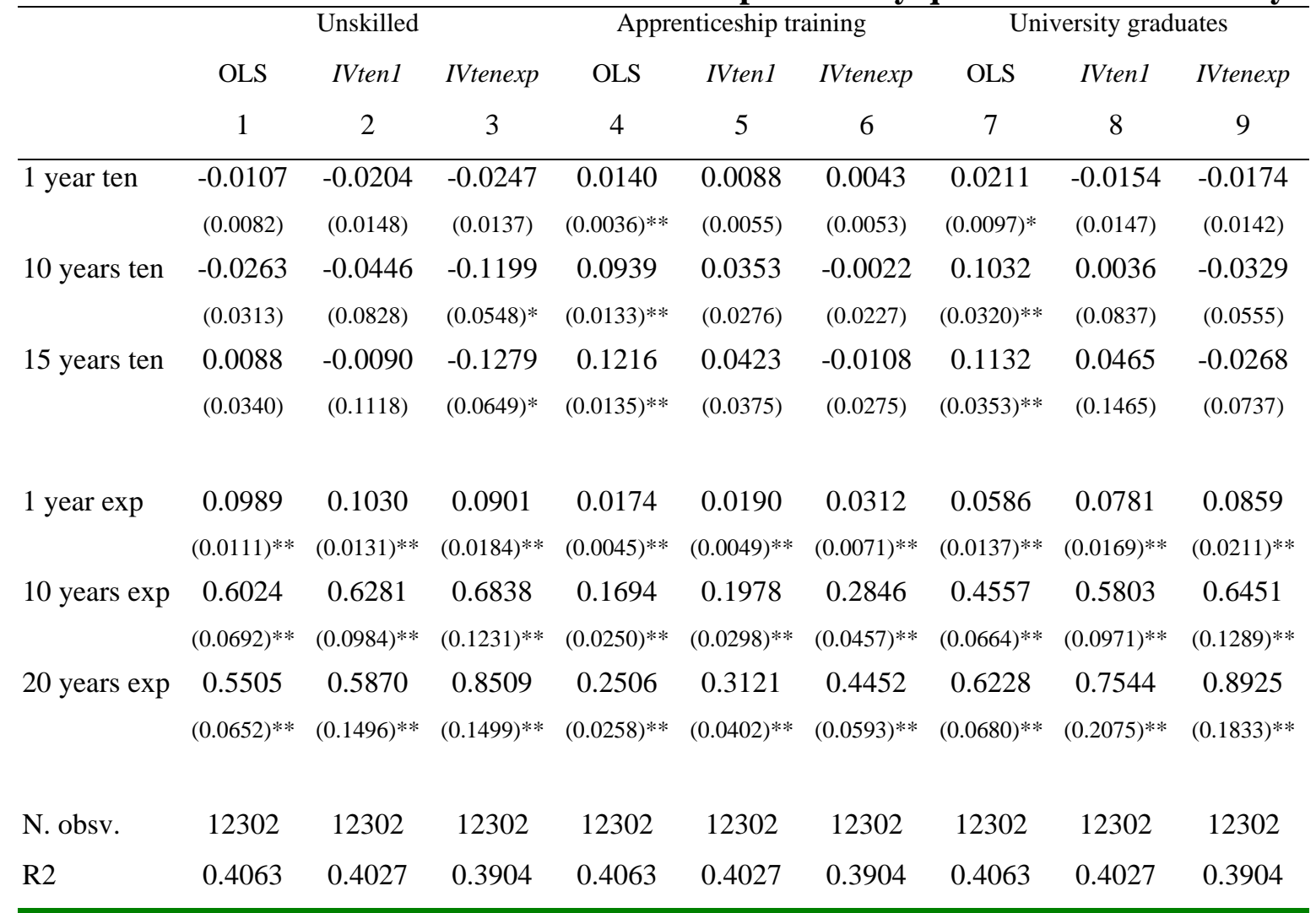

Note: Log-wage returns to $k$ years of tenure (experience) with $k=1,5,10,15,20$ is the cross-product of the row vector of the tenure (experience) polynomial coefficients with a column vector of the form $\left(k, k^{2}, k^{3}, k^{4}\right)$. Values presented are the wage returns and are obtained by applying an exponential transformation to the $\log$ wage returns minus 1 . Standard errors are the square root of a 1 st order Taylor approximation of the corresponding variance.

Returns to experience rise moderately with skill category for the UK - according to the IVten1 estimates returns to 10 years of experience are 61 percent for the unskilled, 74 percent 
for workers with medium skills and approximately 80 percent for university graduates. However, for Germany differences across skill groups are dramatic. For workers who went through apprenticeship training, returns to ten years of experience estimated by IVten 1 are less than 20 percent, with an increase of only 1.9 percent during the first year, while the estimate for the unskilled is 62.8 percent, with an increase of about 10 percent during the first year.

Figure 5 shows IVtenl estimates of wage growth with experience for unskilled workers and workers with apprenticeship training in Germany. Entry wages are 34 percent higher for apprenticeship trainees, but since experience wage returns are considerably lower, their wages fall behind those of the unskilled by the fifth year in the labour market. After 3 years of experience the wage difference between the two groups of workers is no longer significant at the 10 percent level ${ }^{20}$. Figure 5 does not take into account returns to tenure, since these are not significantly different from zero. However, considering the point estimates alone of both returns to tenure and experience, the differences between the two skill groups may lead to a wage advantage for workers with apprenticeship training throughout. For example, for workers who keep their fist job during their entire careers (and accumulate maximum returns to tenure) the wage profile for trained workers would always be above the one for unskilled workers, except for the interval 8 to 13 years of experience in which case both profiles are approximately tangential.

\footnotetext{
${ }^{20}$ Standard errors computed as the square root of a 1st order Taylor approximation of the corresponding variance. For the unskilled the variance is calculated by pre- and post- multiplying the variance covariance matrix of the coefficients of the experience polynomial by a matrix with the values of the experience terms. For the apprenticeship trainees the variance-covariance matrix also includes the coefficient of the education dummy (omitted for the unskilled).
} 


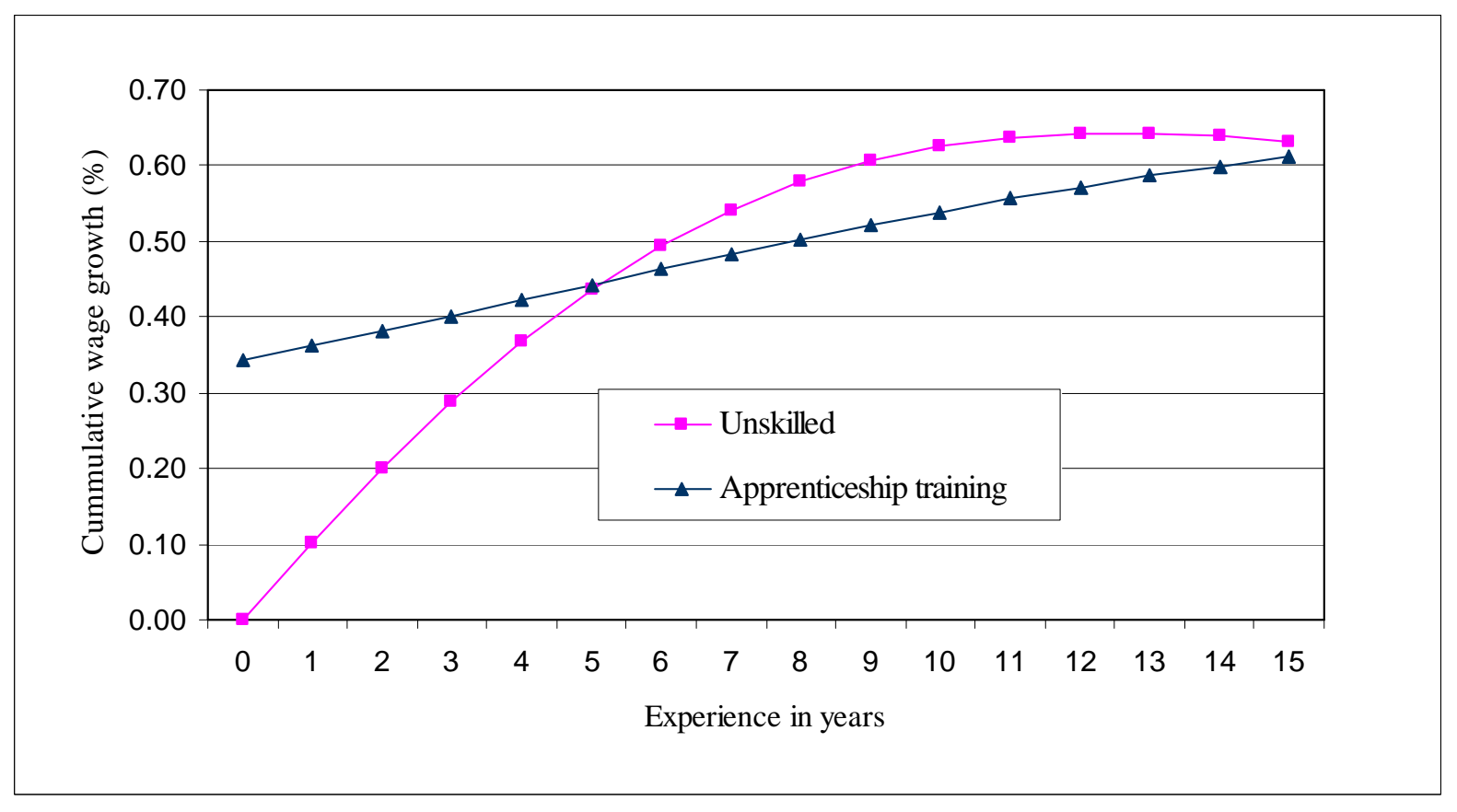

Figure 5: Cumulative wage growth with experience, IVten1 - Germany

For the unskilled, estimates of returns to experience are remarkably similar to those for unskilled workers in the UK. Returns for university graduates are only slightly lower for Germany than for the UK. These results suggest that wage growth due to experience after entering the labour market differs between skill groups in Germany, with very low growth for workers trained within the apprenticeship system, while returns are fairly similar across groups in the UK

\subsection{Estimation of macro trends}

The model in equation (1) allows for three distinct sources of wage growth: the partial effects of experience and tenure, the partial effect of match quality, and the partial effect of the macro trend, always holding individual ability constant. Studies that consider one country 
usually do not report the macro trend in wages. However, this is in itself an interesting variable when comparing different labour markets. In figure 6, we display estimates of macro effects for the two countries. These are coefficients of time dummies (in which the first year is omitted) based on simple OLS estimation. Using the other estimators or instrumental variable estimators give very similar coefficients (see discussion in section 2). We have normalized the German series so that real wages are zero in 1991, the first year in which both countries are observed.

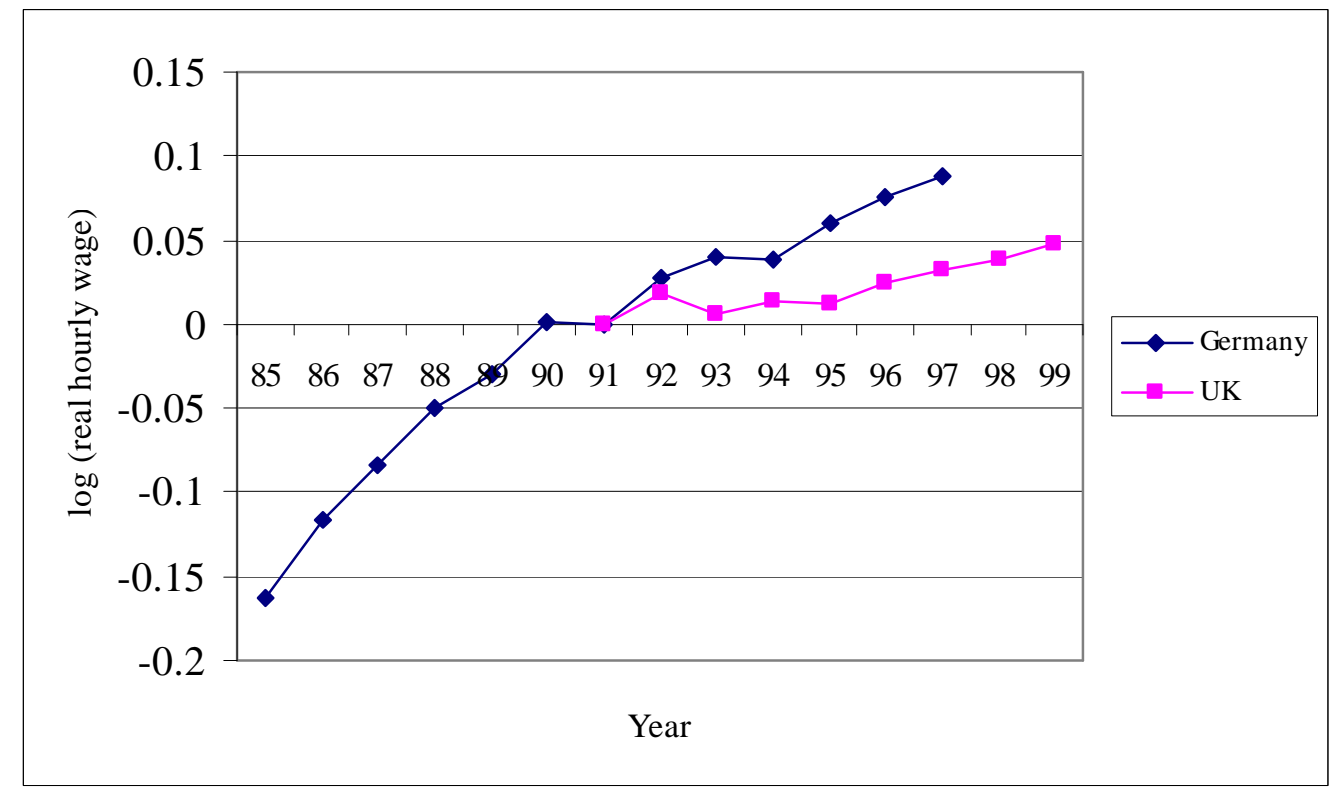

Figure 6: Macro effects estimated by OLS - UK and Germany

Over the period 1991-1997 wage growth is considerably higher in Germany than it is in the UK. On average, the contribution of the economy wide time trend to wage growth is about 2 percent for Germany, but only 0.5 percent for the UK.

One reason for this may be the particular structure of the German labour market, with centralized wage negotiations that affect the vast majority of workers. As we discuss above, 
yearly negotiations between unions and employer associations result in union contracts for types of workers classified by industry and personal characteristics. Currently, there are about 50.000 such contracts in Germany (Hans Boeckler Stiftung 2003). Centralised wage setting may thus be an important motor for individual wage growth in Germany. The macro trend may partly offset the average lower wage growth in Germany due to labour market experience which we have estimated above.

To investigate whether the macro trend affects all education- and experience groups alike, we have estimated log wage regressions, where we interacted a linear year trend with educational dummies, as well as with the level of experience. For Germany, we find that the macro trend contributes mostly to wage growth of the unskilled (on average 2.8 percent per year over the observation window), less so for the apprenticeship trainees (on average 2 percent per year), and the university graduates (1.8 per year). This is not unexpected, as union wages should mainly affect the wage structure at the lower end of the skill distribution. The interaction between experience and the year trend is virtually zero, suggesting that macro effects are similarly distributed across the experience distribution.

For the UK, a not dissimilar picture emerges, with the effect of the time trend on wage growth being largest for the unskilled (at about 0.8 percent), and virtually zero for university graduates. However, estimates are not precise. Again, the interaction between experience and the year trend is zero.

\section{Discussion and Conclusions}

Average returns to labour market experience are, according to our results, markedly higher in the UK than in Germany. The estimates by skill group suggest that at least some of 
this difference is likely to be due to higher "entry wages" for workers who have been through apprenticeship training, since this group of workers' returns to experience estimates are substantially lower than the other two ${ }^{21}$. Workers who undergo the apprenticeship training in Germany are known to receive general or transferable skills (Acemoglu and Pischke, 1999), and their productivity and corresponding wage may increase less after full-time labour market entry, simply because much of the learning is concentrated during the apprenticeship period. In fact, for all other qualification groups in Germany and all qualification groups in the UK, returns to experience have a much steeper slope during the first few years. Estimated returns to experience among unskilled workers are similar in the two countries, but returns to experience among university graduates seem to be somewhat higher in the UK than in Germany.

Our estimates point to low average returns to tenure in both countries. These estimates imply that either the component of workers' skills that is not transferable across employers is unimportant, or that workers do not share the return to job specific human capital in the form of higher wages. Our estimates may however still be downward biased, as we could not correct for the potential upward bias in the experience effect. ${ }^{22}$ It is interesting to note that the OLS estimates for tenure are much lower for both the UK and Germany than estimates found for the US.

A further interesting finding is that wage growth due to the macro trend is substantially higher in Germany than in the UK. Even though this is true across education groups, we find evidence that in Germany the macro trend is contributing mostly to the wage

\footnotetext{
${ }^{21}$ Even though the qualification groups are defined differently in the two countries, it is interesting to note that in Germany entry wages are 34 percent higher for apprenticeship trainees than for unskilled workers, while in the UK medium qualified workers' entry wages are only 11 percent higher than those of the unskilled.
} 
growth of the unskilled, which is compatible with centralised union wage setting, affecting mostly workers at the lower end of the skill distribution.

By exploring the differences between OLS and IV results, we find tentative evidence consistent with "more able" workers having longer job durations in Germany, but not in the UK. There are two possible explanations for why "more able" workers experience longer job tenures in Germany, or, in other words, why "less able" workers are laid off more often or have more incentives to quit.

One possible source of negative selection of job movers is the presence of "sticky wages" (Gibbons and Katz, 1991, p.376). In a context of learning with sticky wages, where in a first stage the employer's information about workers' ability is imperfect, this may lead the firm to layoff workers whose productivity turns out to be "too low"23. An assumption behind this model is that both current employers and prospective employers learn about the worker's ability after a job spell.

It is likely that individual real wages of German workers are "stickier" than those of British workers. British employers are likely to have more discretion with respect to individual wage increases and promotions than German employers who face wage tariffs for different occupations and industries as well as worker-specific characteristics ${ }^{24}$. This would imply that in Germany less able workers would be laid off more often but would not have more incentives to quit.

\footnotetext{
${ }^{22}$ There is some evidence that this is a potential problem. Dustmann and Meghir (2005) use information of firm closure from administrative data to eliminate this potential downward bias; they find that this increases returns to tenure, and decreases returns to experience.

${ }^{23}$ See Dustmann and Schönberg (2004) for a model where the presence of union wages leads firms to lay off workers with productivity below the union wage, once workers' ability is revealed. Their model's main aim is to explain why firms pay for general training within the German Apprenticeship System.

${ }^{24}$ Indirect evidence of this is the fact that both the 90-50 and the 50-10 percentile male wage differentials are larger in the UK than in Germany (see, for example, Blau and Kahn, 1996).
} 
An alternative possible source of negative selection of job movers is asymmetric information between the current and prospective employers about workers' ability. Schönberg (2004) suggests that asymmetric information may result in an ability bias in the estimation of returns to job tenure. In the context of asymmetric information, adverse selection is less important the higher the job mobility (Acemoglu and Pischke, 1998), reducing the expected difference in the average ability of job stayers and job movers. Since overall job mobility is higher in the UK than in Germany, adverse selection would support higher job attachment of more able workers in Germany than in the UK.

Our paper suggests many similarities, but also significant differences between the UK and the German labour market. Surprisingly little comparative work exists so far on the mechanisms that drive wage growth and mobility across the different European economies, and between European economies and those of other industrialised countries. Our paper suggests that institutional differences may lead not only to different underlying structural parameters, but may also affect the way and the extent to which coefficients retrieved by simple regression analysis are confounded with selection and search. 


\section{References}

Abraham, K. G., and Farber, H.., Job Duration, Seniority and Earnings, The American Economic Review, 1987, vol. 77, issue 3 (Jun. 1987), p. 278-279.

Acemoglu, D. and Pischke, J.-S., The Economic Journal 109, 1999 (February), F112-F142.

Acemoglu, D. and Pischke, J.-S., The Structure of Wages and Investment in General Training, Journal of Political Economy, 1999, vol. 107, no. 3, p539-572.

Acemoglu, D. and Pischke, J.-S., Why do Firms Train? Theory and Evidence, Quarterly Journal of Economics, 1998, p.79-119.

Altonji, J. and Shakotko, R., Do Wages Rise with Job Seniority?, Review of Economic Studies, 1987, LIV, 437-459.

Altonji, J. and Williams, N., 1998. The Effects of Labor Market Experience, Job Seniority and Job Mobility on Wage Growth, Research in Labor Economics, Vol 17, p.233-276.

Altonji, J. and Williams, N., 2005. "Do Wages Rise with Job Seniority? A Reassessment" forthcoming in the Industrial and Labor Relations Review.

Becker, G. S., Human Capital: a Theoretical and Empirical Analysis, with Special Reference to Education, New York: Columbia Univ. Press (for NBER), 1964, $3^{\text {rd }}$ ed. Chicago: Univ. Chicago Press (for NBER), 1993.

Bland, Paul, 1999. Trade Union Membership and Recognition 1997-98: an Analysis of Data from the Certification Officer and Labor Force Survey, Labor Market Trends, July, p.343-353.

Blau, F. D. and Kahn, L. M., 1996. International Differences in Male Wage Inequality: Institutions versus Market Forces, Journal of Political Economy, Vol. 104, August, p. 791-836.

Blumen, I., M. Kogan and P.J. McCarthy, (1955) The industrial mobility of labour as a probability process Ithaka, NY: Cornell University Press 
Brown, J. N., Light, A., 1992. Interpreting Panel Data on Job Tenure, Journal of Labor Economics, Vol. 10, No. 3. (Jul.), pp. 219-257.

Burdett, K. (1978): A Theory of Employee Job Search and Quit Rates", American Economic Review, 68, pp. 212-220

Dustmann, C. and C. Meghir (2005): Wages, Experience and Seniority, Review of Economic Studies, $72(1)$

Dustmann, C. and Schönberg, U. (2004), “Training and Union Wages”, IZA working paper No. 1435 EMIRE database, European Employment and Industrial Relations Glossaries, http://www.eurofound.eu.int/emire/emire.html.

Employment Outlook, OECD, 1999.

Finnie, Ross. “Tenure, Experience and Men's and Women's Wages: Panel Estimates from the National Longitudinal Survey of Youth”. Cahier de recherche 9305. Quebec: Univeristé Laval, Groupe de Recherche en Politique Economique, 1993.

Gibbons, R.. and Katz, L. F., Layoffs and Lemons, Journal of Labor Economics, 1991, vol.9, no. 4, p.351-380.

Hans Boeckler Stiftung (2003), WSI-Tarifarchiv, http://www.boeckler.de/cps/rde/xchg/SID3D0AB75D-50FCE228/hbs/hs.xsl/563\%】_20980.html.

Harris, C. and L. Felli (1996), Learning, Wage Dynamics, and Firm Specific Human Capital', Journal of Political Economy, 104, 838-868.

Hashimoto, M. (1981), Firm Specific Human Capital as a Shared investment, American Economic Review, Vol 71.3 pp 475-82

Jovanovic, B. (1979) "Job Matching and the Theory of Turnover", Journal of Political Economy 87, pp 970-992

Light, A and McGarry, K (1998), Job change patterns and the wages of young men, The Review of Economics and Statistics, 80, pp. 276-286 
Marcotte, D. E., The Wage Premium for Job Seniority During the 1980s and Early 1990s, Industrial Relations, 1998, Vol. 37, no. 4.

Metcalf, D., 1999. The Low Pay Commission and the National Minimum Wage, The Economic Journal, 109, February, p. 46-66.

Paqué, K.-L., 1993. Germany: Living with Tight Corporatism, in: J. Hartog and J. Theeuwes (ed.), Labour Market Contracts and Institutions, Elsevier Science Publishers B. V.

Parent, D., Wages and Mobility: The Impact of Employer-Provided Training, Journal of Labor Economics, 1999, vol. 17, no. 2.

Parent, D. (2000), Industry-Specific Capital and the Wage Profile: Evidence from the National Longitudinal Survey of Youth and the Panel Study of Income Dynamics, Journal of Labor Economics, vol. 18 , no.2, p.306-323.

Parent, D (2002), Matching, Human Capital, and the Covariance Structure of Earnings, Labour Economics, pp. 375-404.

Schönberg, U., "Testing for Asymmetric Employer Learning”, 2004, mimeo, University of Rochester.

Scoones, D. and D. Bernhardt (1998), Promotion, Turnover, and Discretionary Human Capital Acquisition, Journal of Labor Economics, Vol. 16, pages 122-41

Topel, R.., Specific Capital, Mobility, and Wages: Wages Rise with Job Seniority, Journal of Political economy, 1991, vol.99, no.1.

Topel, R.., and Ward, M. P., Job Mobility and the Careers of Young Men, The Quarterly Journal of Economics, May 1992, p.439-479. 


\section{Appendix 1: Tables}

Table A1.1: Coefficients of tenure and experience - OLS and IV

\begin{tabular}{|c|c|c|c|c|c|c|c|c|}
\hline & \multicolumn{4}{|c|}{ UK } & \multicolumn{4}{|c|}{ Germany } \\
\hline & OLS & IVten1 & IVten2 & IVtenexp & OLS & IVten1 I & IVten2 & IVtenexp \\
\hline & 1 & 2 & 3 & 4 & 5 & 6 & 7 & 8 \\
\hline \multirow[t]{2}{*}{ Tenure } & 0.0116 & 0.0142 & 0.0135 & 0.0150 & 0.0136 & 0.0038 & 0.0061 & -0.0013 \\
\hline & $(0.0053)^{*}$ & (0.0104) & $(0.0083)$ & $(0.0102)$ & $(0.0034)^{* *}$ & $(0.0051)$ & $(0.0045)$ & $(0.0051)$ \\
\hline \multirow[t]{2}{*}{ Tenure ${ }^{2} \times 10$} & -0.0040 & -0.0129 & -0.0083 & -0.0164 & -0.0094 & -0.0030 & -0.0064 & -0.0019 \\
\hline & $(0.0065)$ & $(0.0140)$ & $(0.0120)$ & $(0.0141)$ & $(0.0042)^{*}$ & $(0.0062)$ & $(0.0057)$ & $(0.0061)$ \\
\hline \multirow[t]{2}{*}{ Tenure ${ }^{3} \times 100$} & 0.0014 & 0.0054 & 0.0040 & 0.0066 & 0.0040 & 0.0017 & 0.0028 & 0.0012 \\
\hline & $(0.0028)$ & $(0.0065)$ & $(0.0058)$ & $(0.0065)$ & $(0.0018)^{*}$ & $(0.0026)$ & $(0.0025)$ & $(0.0026)$ \\
\hline \multirow[t]{2}{*}{ Tenure ${ }^{4} \times 1000$} & -0.0002 & -0.0007 & -0.0006 & -0.0008 & -0.0005 & -0.0002 & -0.0003 & -0.0001 \\
\hline & $(0.0004)$ & $(0.006)$ & (0.0009) & $(0.006)$ & $(0.0003)^{*}$ & $(0.0004)$ & $(0.0003)$ & $(0.0004)$ \\
\hline \multirow[t]{2}{*}{ Experience } & 0.0885 & 0.0904 & 0.0886 & 0.0856 & 0.0345 & 0.0369 & 0.0357 & 0.0472 \\
\hline & $(0.0062)^{* *}$ & $(0.0071)^{* *}$ & $(0.0066)^{* *}$ & $(0.0132)^{* *}$ & $(0.0039) * *$ & $(0.0044)^{* *}$ & $(0.0043)^{* *}$ & $(0.0063)^{* *}$ \\
\hline \multirow[t]{2}{*}{ Experience $^{2} \times 10$} & -0.0452 & -0.0454 & -0.0450 & -0.0374 & -0.0110 & -0.0105 & -0.0093 & -0.0160 \\
\hline & $(0.0050)^{* *}$ & $(0.0056)^{* * *}$ & $(0.0053)^{* *}$ & $(0.0111)^{* *}$ & $(0.0032)^{* *}$ & $(0.0036)^{* *}$ & $(0.0035)^{* *}$ & $(0.0052)^{* *}$ \\
\hline \multirow[t]{2}{*}{ Experience $^{3}$ x100 } & 0.0096 & 0.0097 & 0.0095 & 0.0075 & 0.0005 & 0.0001 & -0.0001 & 0.0020 \\
\hline & $(0.0015)^{* *}$ & $(0.0017)^{* *}$ & $(0.0016)^{* *}$ & $(0.0036)^{*}$ & $(0.001)$ & $(0.0011)$ & $(0.0011)$ & $(0.0017)$ \\
\hline \multirow[t]{2}{*}{ Experience $^{4} \mathrm{x} 1000$} & 0.0008 & -0.0008 & -0.0007 & -0.0006 & 0.0001 & 0.0001 & 0.0020 & 0.0001 \\
\hline & $(0.0002)^{* *}$ & $(0.0002)^{* *}$ & $(0.0002)^{* *}$ & $(0.0004)$ & $(0.0001)$ & $(0.0001)$ & $(0.0001)$ & $(0.0002)$ \\
\hline P-value (tenure) & 24.85 & 0.83 & 5.70 & 0.71 & 58.44 & 1.53 & 1.96 & 1.14 \\
\hline P-value (exp.) & 143.25 & 89.01 & 111.75 & 23.56 & 104.59 & 73.10 & 86.46 & 46.60 \\
\hline N. obsv. & 7073 & 7073 & 7073 & 7073 & 12302 & 12302 & 12302 & 12302 \\
\hline $\mathrm{R} 2$ & 0.3012 & 0.2985 & 0.3008 & 0.2880 & 0.4004 & 0.3979 & 0.3966 & 0.3864 \\
\hline
\end{tabular}

Note: All regressions include marital status, 2 qualification dummies and year dummies. Standard errors in parenthesis.

**-Significant at 1 percent level; *-Significant at 5 percent level. 
Table A1.2: Coefficients of tenure and experience by qualification - UK

\begin{tabular}{|c|c|c|c|}
\hline & OLS & IVten1 & IVtenexp \\
\hline Ten & $\begin{array}{l}0.0143 \\
(0.0099)\end{array}$ & $\begin{array}{l}0.0234 \\
(0.0225)\end{array}$ & $\begin{array}{l}0.0214 \\
(0.0207)\end{array}$ \\
\hline Ten $2 \times 10$ & $\begin{array}{c}-0.0092 \\
(0.0113)\end{array}$ & $\begin{array}{c}-0.0250 \\
(0.0282)\end{array}$ & $\begin{array}{c}-0.0260 \\
(0.0274)\end{array}$ \\
\hline Ten $3 \times 100$ & $\begin{array}{l}0.0037 \\
(0.0045)\end{array}$ & $\begin{array}{l}0.0098 \\
(0.0126)\end{array}$ & $\begin{array}{l}0.0100 \\
(0.0122)\end{array}$ \\
\hline Ten $4 \times 1000$ & $\begin{array}{r}-0.0005 \\
(0.0006)\end{array}$ & $\begin{array}{r}-0.0015 \\
(0.0018)\end{array}$ & $\begin{array}{c}-0.0015 \\
(0.0017)\end{array}$ \\
\hline TenxEd2 & $\begin{array}{l}0.0111 \\
(0.0136)\end{array}$ & $\begin{array}{c}-0.0145 \\
(0.0291)\end{array}$ & $\begin{array}{c}-0.0124 \\
(0.0267)\end{array}$ \\
\hline Ten $2 x \operatorname{Ed} 2 x 10$ & $\begin{array}{r}-0.0213 \\
(0.0169)\end{array}$ & $\begin{array}{l}0.0105 \\
(0.0374)\end{array}$ & $\begin{array}{l}0.0089 \\
(0.0365)\end{array}$ \\
\hline Ten3xEd2x100 & $\begin{array}{l}0.0107 \\
(0.0074)\end{array}$ & $\begin{array}{c}-0.0030 \\
(0.0172)\end{array}$ & $\begin{array}{c}-0.0027 \\
(0.0167)\end{array}$ \\
\hline Ten4xEd2x1000 & $\begin{array}{r}-0.0017 \\
(0.0010)\end{array}$ & $\begin{array}{l}0.0007 \\
(0.0025) \\
\end{array}$ & $\begin{array}{l}0.0005 \\
(0.0024) \\
\end{array}$ \\
\hline TenxEd3 & $\begin{array}{c}-0.0228 \\
(0.0138)\end{array}$ & $\begin{array}{c}-0.0153 \\
(0.0293)\end{array}$ & $\begin{array}{c}-0.0107 \\
(0.0267)\end{array}$ \\
\hline Ten $2 x E d 3 x 10$ & $\begin{array}{c}0.0415 \\
(0.0173)^{* *}\end{array}$ & $\begin{array}{l}0.0267 \\
(0.0373)\end{array}$ & $\begin{array}{l}0.0253 \\
(0.0366)\end{array}$ \\
\hline Ten $3 \times E d 3 \times 100$ & $\begin{array}{c}-0.0199 \\
(0.0077)^{* *}\end{array}$ & $\begin{array}{c}-0.0124 \\
(0.0173)\end{array}$ & $\begin{array}{c}-0.0122 \\
(0.0170)\end{array}$ \\
\hline Ten $4 x E d 3 \times 1000$ & $\begin{array}{c}0.0028 \\
(0.0011)^{* *}\end{array}$ & $\begin{array}{l}0.0022 \\
(0.0026)\end{array}$ & $\begin{array}{l}0.0021 \\
(0.0025)\end{array}$ \\
\hline Exp & $\begin{array}{c}0.0800 \\
(0.0168)^{* *}\end{array}$ & $\begin{array}{c}0.0801 \\
(0.0192)^{* *}\end{array}$ & $\begin{array}{c}0.0778 \\
(0.0336) * *\end{array}$ \\
\hline $\operatorname{Exp} 2 \times 10$ & $\begin{array}{c}-0.0436 \\
(0.0133)^{* *}\end{array}$ & $\begin{array}{l}-0.0402 \\
(0.0148)^{* *}\end{array}$ & $\begin{array}{c}-0.0323 \\
(0.0270)\end{array}$ \\
\hline Exp3x100 & $\begin{array}{c}0.0101 \\
(0.0041)^{* * *}\end{array}$ & $\begin{array}{l}0.0086 \\
(0.0046)\end{array}$ & $\begin{array}{l}0.0063 \\
(0.0085)\end{array}$ \\
\hline Exp4x1000 & $\begin{array}{c}-0.0009 \\
(0.0004)^{* *}\end{array}$ & $\begin{array}{c}-0.0006 \\
(0.0005) \\
\end{array}$ & $\begin{array}{c}-0.0005 \\
(0.0009) \\
\end{array}$ \\
\hline ExpxEd2 & $\begin{array}{l}0.0010 \\
(0.0191)\end{array}$ & $\begin{array}{l}0.0016 \\
(0.0226)\end{array}$ & $\begin{array}{c}-0.0104 \\
(0.0384)\end{array}$ \\
\hline $\operatorname{Exp} 2 x \operatorname{Ed} 2 \times 10$ & $\begin{array}{l}0.0103 \\
(0.0153)\end{array}$ & $\begin{array}{l}0.0094 \\
(0.0177)\end{array}$ & $\begin{array}{l}0.0151 \\
(0.0313)\end{array}$ \\
\hline Exp3xEd2x100 & $\begin{array}{c}-0.0041 \\
(0.0047)\end{array}$ & $\begin{array}{c}-0.0037 \\
(0.0056)\end{array}$ & $\begin{array}{c}-0.0055 \\
(0.0099)\end{array}$ \\
\hline Exp4xEd2x1000 & $\begin{array}{l}0.0004 \\
(0.0005) \\
\end{array}$ & $\begin{array}{l}0.0003 \\
(0.0006) \\
\end{array}$ & $\begin{array}{l}0.0006 \\
(0.0011) \\
\end{array}$ \\
\hline ExpxEd3 & $\begin{array}{l}0.0378 \\
(0.0204)\end{array}$ & $\begin{array}{l}0.0362 \\
(0.0235)\end{array}$ & $\begin{array}{l}0.0308 \\
(0.0428)\end{array}$ \\
\hline $\operatorname{Exp} 2 \times E d 3 \times 10$ & $\begin{array}{c}-0.0364 \\
(0.0170)^{* * *}\end{array}$ & $\begin{array}{c}-0.0364 \\
(0.0190)\end{array}$ & $\begin{array}{c}-0.0408 \\
(0.0350)\end{array}$ \\
\hline Exp3xEd3x100 & $\begin{array}{c}0.0119 \\
(0.0055)^{* *}\end{array}$ & $\begin{array}{c}0.0123 \\
(0.0062)^{* *}\end{array}$ & $\begin{array}{l}0.0145 \\
(0.0113)\end{array}$ \\
\hline Exp4xEd3x1000 & $\begin{array}{c}-0.0013 \\
(0.0006)^{* *}\end{array}$ & $\begin{array}{c}-0.0014 \\
(0.0007)^{* *}\end{array}$ & $\begin{array}{c}-0.0017 \\
(0.0012)\end{array}$ \\
\hline $\begin{array}{l}\text { Number of observ. } \\
\text { R-squared }\end{array}$ & $\begin{array}{c}7073 \\
0.3136 \\
\end{array}$ & $\begin{array}{c}7073 \\
0.2903 \\
\end{array}$ & $\begin{array}{c}7073 \\
0.279 \\
\end{array}$ \\
\hline
\end{tabular}

Note: All regressions include marital status, 2 qualification dummies and year dummies. Ed2 is a dummy variable equal to 1 for the medium qualified, and Ed3 is equal to 1 for the highly qualified. (definitions in data appendix).Standard errors in parenthesis. **-Significant at 1 percent level; *- Significant at 5 percent level. 
Table A1.3: Coefficients of tenure and experience by qualification - Germany

\begin{tabular}{|c|c|c|c|}
\hline & OLS & IVten1 & IVtenexp \\
\hline Ten & $\begin{array}{c}-0.0119 \\
(0.0093)\end{array}$ & $\begin{array}{c}-0.0233 \\
(0.0165)\end{array}$ & $\begin{array}{c}-0.0269 \\
(0.0155)\end{array}$ \\
\hline Ten $2 \times 10$ & $\begin{array}{l}0.0110 \\
(0.0108)\end{array}$ & $\begin{array}{l}0.0279 \\
(0.0167)\end{array}$ & $\begin{array}{l}0.0198 \\
(0.0169)\end{array}$ \\
\hline Ten3x100 & $\begin{array}{c}-0.0018 \\
(0.0044)\end{array}$ & $\begin{array}{c}-0.0105 \\
(0.0067)\end{array}$ & $\begin{array}{c}-0.0064 \\
(0.0067)\end{array}$ \\
\hline Ten $4 \times 1000$ & $\begin{array}{l}0.0000 \\
(0.0006)\end{array}$ & $\begin{array}{l}0.0013 \\
(0.0009)\end{array}$ & $\begin{array}{l}0.0007 \\
(0.0009)\end{array}$ \\
\hline TenxEd2 & $\begin{array}{c}0.0266 \\
(0.0101)^{* *}\end{array}$ & $\begin{array}{l}0.0330 \\
(0.0177)\end{array}$ & $\begin{array}{l}0.0321 \\
(0.0166)\end{array}$ \\
\hline Ten $2 x E d 2 \times 10$ & $\begin{array}{c}-0.0193 \\
(0.0119)\end{array}$ & $\begin{array}{c}-0.0382 \\
(0.0183)^{* *}\end{array}$ & $\begin{array}{c}-0.0288 \\
(0.0184)\end{array}$ \\
\hline Ten $3 \times E d 2 \times 100$ & $\begin{array}{l}0.0046 \\
(0.0050)\end{array}$ & $\begin{array}{c}0.0151 \\
(0.0074)^{* *}\end{array}$ & $\begin{array}{l}0.0105 \\
(0.0074)\end{array}$ \\
\hline Ten $4 \times$ Ed $2 \times 1000$ & $\begin{array}{c}-0.0003 \\
(0.0007)\end{array}$ & $\begin{array}{c}-0.0019 \\
(0.0010)\end{array}$ & $\begin{array}{c}-0.0012 \\
(0.0010)\end{array}$ \\
\hline TenxEd3 & $\begin{array}{c}0.0347 \\
(0.0144)^{* *}\end{array}$ & $\begin{array}{l}0.0048 \\
(0.0237)\end{array}$ & $\begin{array}{l}0.0066 \\
(0.0226)\end{array}$ \\
\hline Ten $2 \times E d 3 \times 10$ & $\begin{array}{c}-0.0307 \\
(0.0200)\end{array}$ & $\begin{array}{l}0.0028 \\
(0.0295)\end{array}$ & $\begin{array}{l}0.0093 \\
(0.0297)\end{array}$ \\
\hline Ten3xEd3x100 & $\begin{array}{l}0.0095 \\
(0.0099)\end{array}$ & $\begin{array}{c}-0.0033 \\
(0.0153)\end{array}$ & $\begin{array}{c}-0.0077 \\
(0.0150)\end{array}$ \\
\hline Ten $4 x E d 3 x 1000$ & $\begin{array}{c}-0.0010 \\
(0.0016)\end{array}$ & $\begin{array}{l}0.0006 \\
(0.0026)\end{array}$ & $\begin{array}{l}0.0012 \\
(0.0025)\end{array}$ \\
\hline Exp & $\begin{array}{c}0.1013 \\
(0.0111)^{* *}\end{array}$ & $\begin{array}{c}0.1054 \\
(0.0130)^{* *}\end{array}$ & $\begin{array}{c}0.0912 \\
(0.0184)^{* *}\end{array}$ \\
\hline $\operatorname{Exp} 2 \times 10$ & $\begin{array}{c}-0.0727 \\
(0.0106)^{* *}\end{array}$ & $\begin{array}{c}-0.0768 \\
(0.0133)^{* *}\end{array}$ & $\begin{array}{c}-0.0501 \\
(0.0174)^{* *}\end{array}$ \\
\hline Exp3x100 & $\begin{array}{c}0.0206 \\
(0.0037)^{* *}\end{array}$ & $\begin{array}{c}0.0223 \\
(0.0046)^{* *}\end{array}$ & $\begin{array}{c}0.0121 \\
(0.0058)^{* *}\end{array}$ \\
\hline Exp4x1000 & $\begin{array}{c}-0.0020 \\
(0.0004)^{* *}\end{array}$ & $\begin{array}{c}-0.0023 \\
(0.0005)^{* *}\end{array}$ & $\begin{array}{c}-0.0011 \\
(0.0006) \\
\end{array}$ \\
\hline ExpxEd2 & $\begin{array}{c}-0.0841 \\
(0.0120)^{* *}\end{array}$ & $\begin{array}{c}-0.0868 \\
(0.0140)^{* *}\end{array}$ & $\begin{array}{c}-0.0599 \\
(0.0198)^{* *}\end{array}$ \\
\hline $\operatorname{Exp} 2 x \operatorname{Ed} 2 \times 10$ & $\begin{array}{c}0.0734 \\
(0.0112)^{* *}\end{array}$ & $\begin{array}{c}0.0790 \\
(0.0139)^{* *}\end{array}$ & $\begin{array}{c}0.0443 \\
(0.0184)^{* *}\end{array}$ \\
\hline Exp3xEd2x100 & $\begin{array}{c}-0.0232 \\
(0.0039)^{* *}\end{array}$ & $\begin{array}{c}-0.0256 \\
(0.0048)^{* * *}\end{array}$ & $\begin{array}{l}-0.0127 \\
(0.0061)^{* *}\end{array}$ \\
\hline Exp4xEd2x1000 & $\begin{array}{c}0.0024 \\
(0.0004)^{* *}\end{array}$ & $\begin{array}{c}0.0027 \\
(0.0005)^{* *}\end{array}$ & $\begin{array}{l}0.0012 \\
(0.0007)\end{array}$ \\
\hline ExpxEd3 & $\begin{array}{c}-0.0417 \\
(0.0182)^{* *}\end{array}$ & $\begin{array}{c}-0.0259 \\
(0.0218)\end{array}$ & $\begin{array}{c}-0.0039 \\
(0.0282)\end{array}$ \\
\hline Exp2xEd $3 \times 10$ & $\begin{array}{c}0.0451 \\
(0.0197)^{* *}\end{array}$ & $\begin{array}{l}0.0324 \\
(0.0248)\end{array}$ & $\begin{array}{l}0.0000 \\
(0.0296)\end{array}$ \\
\hline Exp3xEd3x100 & $\begin{array}{c}-0.0144 \\
(0.0080)\end{array}$ & $\begin{array}{c}-0.0105 \\
(0.0115)\end{array}$ & $\begin{array}{l}0.0019 \\
(0.0120)\end{array}$ \\
\hline Exp4xEd3x1000 & $\begin{array}{l}0.0014 \\
(0.0011)\end{array}$ & $\begin{array}{l}0.0010 \\
(0.0017)\end{array}$ & $\begin{array}{c}-0.0003 \\
(0.0016)\end{array}$ \\
\hline $\begin{array}{l}\text { Number of observ. } \\
\text { R-squared }\end{array}$ & $\begin{array}{r}12302 \\
0.4063 \\
\end{array}$ & $\begin{array}{r}12302 \\
0.4027 \\
\end{array}$ & $\begin{array}{l}12302 \\
0.3904 \\
\end{array}$ \\
\hline
\end{tabular}

Note: All regressions include marital status, 2 qualification dummies and year dummies. Ed 2 is a dummy variable equal to 1 for the medium qualified, and Ed3 is equal to 1 for the highly qualified. (definitions in data appendix).Standard errors in parenthesis.

**-Significant at 1 percent level; *- Significant at 5 percent level. 


\section{Appendix 2: Bias in the IVten2 estimator}

In the empirical section we use as an instrumental variable for tenure its deviations

from individual means. We call this instrumental variable estimator IVten2. If $\tilde{T}_{i j t}$ is the predicted value of the first stage, where tenure is regressed on its deviations from the individual mean, then we have the following auxiliary regressions:

$$
\begin{gathered}
A_{i}=b_{1}^{\text {IVten } 2} X_{i j t}+b_{2}^{\text {IVten } 2} \widetilde{T}_{i j t}+\zeta_{i j t} \\
\theta_{i j}=c_{1}^{\text {IVten2 } 2} X_{i j t}+c_{2}^{\text {IVten2 } 2} \widetilde{T}_{i j t}+\varsigma_{i j t} \\
W_{i j t}=\beta_{0} \gamma_{t}+\left(\beta_{1}+b_{1}^{\text {IVten2 }}+c_{1}^{\text {IVten } 2}\right) X_{i j t}+\left(\beta_{2}+b_{2}^{\text {IVten } 2}+c_{2}^{\text {IVten2 } 2}\right) \widetilde{T}_{i j t}+\zeta_{i j t}+\zeta_{i j t}+v_{i j t}
\end{gathered}
$$

The biases in the returns to tenure and experience are given by the expressions below:

$$
\begin{aligned}
& \beta_{1}^{\text {IVten } 2}-\beta_{1}=b_{1}^{\text {IVten } 2}+c_{1}^{\text {IVten } 2} \\
& \beta_{2}^{\text {IVten } 2}-\beta_{2}=b_{2}^{\text {IVten } 2}+c_{2}^{\text {IVten } 2}
\end{aligned}
$$

Where:

$$
b_{2}^{I V t e n 2}=\frac{-\gamma_{X \tilde{T}} \operatorname{Cov}\left(X_{i j t}, A_{i}\right)}{\operatorname{Var}\left(\widetilde{T}_{i j t}\right)\left[1-\left(\operatorname{Corr}\left(\widetilde{T}_{i j t}, X_{i j t}\right)\right)^{2}\right]}
$$




$$
c_{2}^{I V t e n 2}=\frac{\operatorname{Cov}\left(\tilde{T}_{i j t}, \theta_{i j}\right)-\gamma_{X \tilde{T}} \operatorname{Cov}\left(X_{i j t}, \theta_{i j}\right)}{\operatorname{Var}\left(\widetilde{T}_{i j t}\right)\left[1-\left(\operatorname{Corr}\left(\tilde{T}_{i j t}, X_{i j t}\right)\right)^{2}\right]}
$$

Recall that the bias in the returns to tenure from IVten 1 can be written as:

$$
\begin{aligned}
& \beta_{2}^{\text {IVten } 1}-\beta_{2}=b_{2}^{\text {IVten } 1}+c_{2}^{\text {IVten } 1} \\
& b_{2}^{\text {IVten } 1}=\frac{-\gamma_{X X \hat{T}} \operatorname{Cov}\left(X_{i j t}, A_{i}\right)}{\operatorname{Var}\left(\hat{T}_{i j t}\right)\left[1-\left(\operatorname{Corr}\left(\hat{T}_{i j t}, X_{i j t}\right)\right)^{2}\right]} \\
& c_{2}^{\text {IVten } 1}=\frac{-\gamma_{X \hat{T}} \operatorname{Cov}\left(X_{i j t}, \hat{\theta}_{i j}\right)}{\operatorname{Var}\left(\hat{T}_{i j t}\right)\left[1-\left(\operatorname{Corr}\left(\hat{T}_{i j t}, X_{i j t}\right)\right)^{2}\right]}
\end{aligned}
$$

From (4), (5), (7) and (8) it is clear that if

$$
\frac{-\gamma_{X \hat{T}}}{\operatorname{Var}\left(\hat{T}_{i j t}\right)\left[1-\left(\operatorname{Corr}\left(\hat{T}_{i j t}, X_{i j t}\right)\right)^{2}\right]}=\frac{-\gamma_{X \tilde{T}}}{\operatorname{Var}\left(\tilde{T}_{i j t}\right)\left[1-\left(\operatorname{Corr}\left(\tilde{T}_{i j t}, X_{i j t}\right)\right)^{2}\right]}
$$

$$
\text { then } \beta_{2}^{I \text { Vten } 2}-\beta_{2}^{I \text { Vten } 1}=\frac{\operatorname{Cov}\left(\widetilde{T}_{i j t}, \theta_{i j}\right)}{\operatorname{Var}\left(\widetilde{T}_{i j t}\right)\left[1-\left(\operatorname{Corr}\left(\widetilde{T}_{i j t}, X_{i j t}\right)\right)^{2}\right]}
$$

One could therefore assess the importance of the association between match quality and job duration by comparing the estimates given by IVten I and IVten2. However, without further assumptions we can only state that the larger the association between job match quality and job duration, the higher the probability that $\beta_{2}^{\text {IVten } 2}>\beta_{2}^{\text {IVten1 }}$.

Intuitively, it is true that IVtenI produces an estimate of returns to tenure free from the bias due to the correlation between tenure and both the individual and job match effects while IVten 2 produces an estimate of returns to tenure only free from the bias due to the correlation between tenure and the individual fixed effect. However returns to tenure are also biased due 
to the correlation between experience and the individual and the job match components, and the magnitude of this bias depends on the association between experience and $\tilde{T}_{i j t}$ or $\hat{T}_{i j t}$. For this reason one can not establish that the bias in $\beta_{2}^{\text {IVten } 2}$ is larger than the bias in $\beta_{2}^{\text {IVten } 1}$.

\section{Appendix 3: The data}

\section{British Household Panel Survey}

Tenure: is the total number of years in which the individual works for the same employer. It is constructed for all individuals that are in paid employment. It is not constructed for self-employed, since these are excluded from the sample. Individuals are asked to give the starting date of the job spell, and not the spell with employer ${ }^{25}$. For example, if the individual is promoted, the date collected is the date of promotion. In order to track down the starting date with the present employer, we go back as many spells as there are jobs changes with the same employer, which involves using the information of the inter-wave history files and the retrospective data in many instances. We therefore add the time spent in the various spells within the same employer in order to compute tenure with the employer. When linking the job spell information in the various yearly questionnaires and the retrospective data collected in waves 2 and 3 one is confronted with the overlapping of more than one source of information for the same spell, or part of it. Conflicting

\footnotetext{
${ }^{25}$ Question Text: "What was the date you started working in your present position? If you have been promoted or changed grades, please give me the date of that change. Otherwise please give me the date when you started doing the job you are doing now for your present employer."
} 
answers are resolved by giving priority to the information collected closest to the event occurrence. This is because recall error is likely to increase with the time elapsed between an event and the time of interview. In addition, in some cases in two consecutive waves although the job starting date given in the later wave takes place before the previous wave interview, the discrepancy between the two start dates makes it clear that they refer to two different job spells. We therefore also adopted the following rule: if the starting date of a given spell occurs just before the previous wave interview date (i.e., during the previous year) and it is more than 1 year apart from the starting date recorded in the previous interview, then it is assumed that this spell started just after the previous wave interview.

Experience: sums the individual's time spent in paid employment ${ }^{26}$ since leaving full time education. Similar to the tenure variable, it combines the information from the various yearly questionnaires and the retrospective data collected in waves 2 and 3.

Skills: The skill variable is constructed from the information on the individuals' highest educational qualification. We classified workers into three skill groups as follows. Unskilled: No qualifications, other qualifications, apprenticeship, CSE, commercial qualifications, no O levels. Medium skilled: $\mathrm{O}$ levels or equivalent, nursing qualifications, teaching qualifications, A levels. University Graduates: Higher degree, $1^{\text {st }}$ Degree, other higher. 
Wage: Nominal hourly wage is obtained by first dividing the current job usual gross monthly pay by 4.33 to obtain weekly wage and then by weekly hours. Weekly hours are the sum of the number of hours normally worked per week and the number of overtime hours in a normal week. The nominal hourly wage is then deflated with the Retail Prices Index ${ }^{27}$ to obtain real hourly wages.

\section{German Socio-Economic Panel}

Tenure: The variable tenure in the job was constructed using the information about the exact year and month the individual has started current job, up to the time of interview. This variable was rounded to the nearest year.

Experience: The number of years of labour market experience is constructed in two stages. The first stage uses the yearly biographical scheme containing employment information from the age of 16 to the first wave of the panel to construct total experience at the entry of the panel. Both part-time and full-time spells are taken into account. The second stage uses the calendar available for each wave listing all labour market activities for each month in the year preceding the interview. This information is added to the information computed in the first stage to construct experience at each wave. This variable was rounded to the nearest year.

\footnotetext{
${ }^{26}$ Self-employment spells are also included in experience, even though they do not make much difference, since our sample does not include those that are self-employed at the time of the survey.

${ }^{27}$ Monthly values are averaged for each year with 1991 as base year. Source: Economic Trends, Annual Supplement, 1998, Office for National Statistics.
} 
Skills: Given the apprenticeship training system in Germany, workers are divided into those with no apprenticeship training and no university degree - Unskilled, those with apprenticeship training - Medium skilled or apprenticeship trainees, and those with a university degree - University graduates.

Wage: Real hourly wage was constructed using the information on the reported gross earnings in the month preceding the interview. These excluded any additional payments, e.g., holiday money or back-pay and included money earned for overtime. This amount was divided by 4.33 to obtain weekly wage and then by weekly hours. Weekly hours are a derived variable with the actual number of hours worked per week. This is based on the information given at the question: And how much on average does your actual working week amount to, with possible overtime? Gross nominal hourly wages were deflated by the German consumer price index. 